\title{
Synthesis, reactivity and biological activity of 5-alkoxymethyluracil analogues
}

Lucie Brulikova and Jan Hlavac

\section{Review}

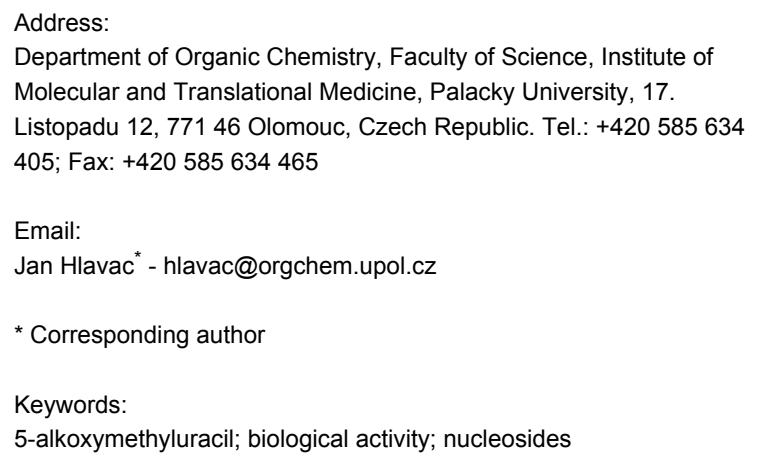

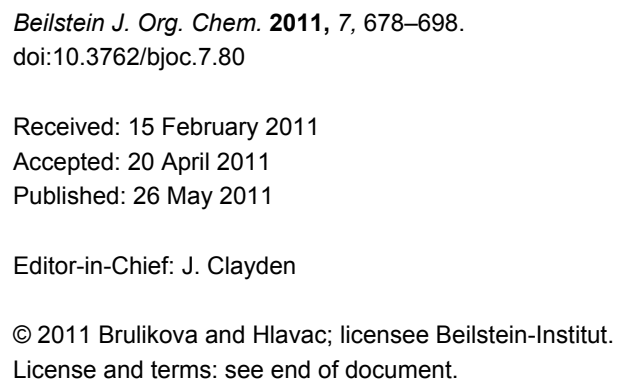

\section{Abstract}

This review article summarizes the results of a long-term investigation of 5-alkoxymethyluracil analogues and is aimed, in particular, at methods of syntheses. Most of the presented compounds were synthesized in order to evaluate their biological activity, therefore, a brief survey of biological activity, especially antiviral, cytotoxic and antibacterial, is also reported.

\section{Review}

\section{Introduction}

Modifications of nucleic acid components play a significant role in the field of nucleic acids research. In particular, nucleoside analogues find broad therapeutic applications in anticancer treatments and antiviral chemotherapy. In anticancer chemotherapy the huge amount of knowledge concerning processes taking place through the cell cycle has enabled researchers to break through and to understand the mechanisms of action of many anticancer agents. 5-Fluorouracil, for instance, was one of the first [1] and most investigated anticancer drugs, either chemically or biologically, and triggered the research of 5-substituted pyrimidine analogues.

The elucidation of the life cycle of a virus is crucial in antiviral chemotherapy. Several 5-substituted pyrimidine analogues capable of affecting the life cycle of viruses were discovered as highly active antiviral agents. Two such drugs with antiviral properties are 5-iodo-2'-deoxyuridine, discovered in the 1960s as the first agent that is active against Herpes simplex and Varicella zoster viruses [2,3], and 5-vinyl-2'-deoxyuridine, exhibiting high activity against HSV [4,5], which in turn led to studies on the synthesis and biological activity of its analogues.

From these pieces of knowledge, we draw inspiration for the development of new potent biologically active compounds; Compounds that might be more selective, more specific and much less toxic for organisms.

One of those groups of investigated derivatives is a group of uracil analogues modified at the 5 position by an ether or ester moiety. Since a vast number of C-5 modified pyrimidine 
analogues are known, this review is focused on a group of selected compounds with specific substituents (Figure 1) and most attention is paid to the studies on synthesis of selected derivatives. A brief survey of the biological activity of investigated compounds is also reported. The following chapters concerning the synthesis are arranged according to the products of synthetic routes.<smiles>[R]OC([R])c1cn([125I])c(=O)[nH]c1=O</smiles>

$\mathrm{R}^{3}$
$\mathrm{R}^{1}=\mathrm{alkyl}$

$\mathrm{R}^{2}=$ alkyl, carbocycle, heterocycle $\mathrm{R}^{3}=\mathrm{H}$, carbocycle, heterocycle
Figure 1: Investigated derivatives.

\section{Synthesis}

\section{Synthesis of alkoxy-haloalkyl derivatives}

The most numerous and also the most investigated group of the above mentioned derivatives is a group of alkoxy-haloalkyl compounds derived either from uracil or nucleosides (Figure 2). With regard to the high variability of sugar moiety, the description of all the compounds is divided into sections according to the nature of the furanose present.<smiles>[R]C([R])c1cn([R])c(=O)[nH]c1=O</smiles>

$\mathrm{R}^{1}=$ alkyl

$\mathrm{R}^{2}=$ halogenalkyl

$\mathrm{R}^{3}=\mathrm{H}$, ribose, 2'-deoxyribose, arabinose, 2'-fluoro-2'-deoxyribose, 2'-deoxy-4'-C-methylribose

Figure 2: Modifications of uracil ring.

2'-Deoxyuridine analogues: The earliest article describing 2'-deoxyuridine analogues was focused on uracil analogues modified at position 5 by a fluorine containing moiety [6]. Bases or nucleosides substituted by fluorine have been investigated as potent anticancer agents since the 1960s. Nevertheless, many such modified compounds were also synthesized in order to investigate their antiviral activity. As a consequence of interest in biologically active fluoro derivatives, Bergstrom and co-workers carried out the synthesis of 5-(3,3,3-trifluoro-1methoxypropyl)-2'-deoxyuridine (1) (Figure 3) which was the first perfluoro derivative from the group of aforementioned compounds.

The synthetic route to the desired fluoro compound 1 utilized the known reaction [7] between the organomercuri intermediate, 5-chloromercuri-2'-deoxyuridine, and a palladium catalyst. The

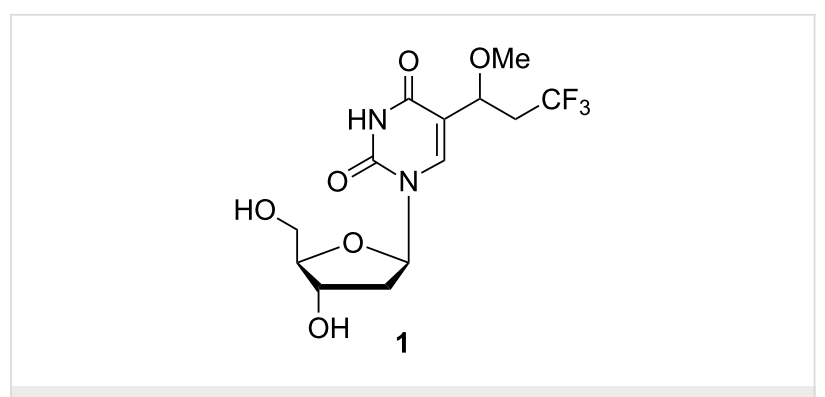

Figure 3: 5-(3,3,3-Trifluoro-1-methoxypropyl)-2'-deoxyuridine (1).

reaction, carried out in methanol, afforded $17 \%$ of $(E)-5-(3,3,3-$ trifluoro-1-propenyl)-2'-deoxyuridine (6) and 36\% of 5-(3,3,3trifluoro-1-methoxypropyl)-2'-deoxyuridine (1) (Scheme 1).

Shortly after publishing the successful synthesis of trifluoro nucleoside 1, Bergstrom and co-workers reported a presumed mechanism for its formation (Scheme 1) [8]. In addition, they also focused their research on isopropyloxy analogue 2 .

Reaction of 3,3,3-trifluoropropene with 5-chloromercuri-2'deoxyuridine (4) in methanol gave two major products $(E)-5$ (3,3,3-trifluoro-1-propenyl)-2'-deoxyuridine (6) and derivative $\mathbf{1}$ in an approximately 1:2 ratio. The authors also carried out the synthesis in other solvents, such as $N, N$-dimethylformamide, 2-propanol or acetonitrile, and found that the use of solvents other than methanol led to decreased yields of the C-5 substituted products. The utilization of 2-propanol, for instance, afforded unsaturated derivative 6 in $8 \%$ yield and 5-(3,3,3trifluoro-1-(2-propyloxy)prop-1-yl)-2'-deoxyuridine (2) in 12\% yield. Moreover, fluoro compound $\mathbf{1}$ can be converted to the propenyl derivative 6 by treating with a mixture of trifluoroacetic acid and trifluoroacetic acid anhydride. Interestingly, a third product was isolated from the reaction mixture when similar reactions of 5-chloromercuri-2'-deoxyuridine (4) with 3,3,3-trifluoropropene were carried out. This was shown to be 5-(3,3,3-trifluoro-1-hydroxypropyl)-2'-deoxyuridine (3) which was obtained in $38-40 \%$ yield, however, the authors were unable to account for its formation.

An attempt at hydrogenolysis of the methoxy group of derivative 1 using $\mathrm{H}_{2}$ and $\mathrm{Pd} / \mathrm{C}$ afforded 5-(3,3,3-trifluoro-1methoxyprop-1-yl)-5,6-dihydro-2'-deoxyuridine (8) indicating that ring reduction occurred instead of hydrogenolysis (Scheme 2).

The synthesis of a large range of alkoxyhalogenalkyl 2'-deoxyuridine nucleosides was successfully performed by Kumar and co-workers over the years 1989-1994 [9-13]. Almost all of these compounds were synthesized in order to evaluate their biological activity and especially their antiviral 

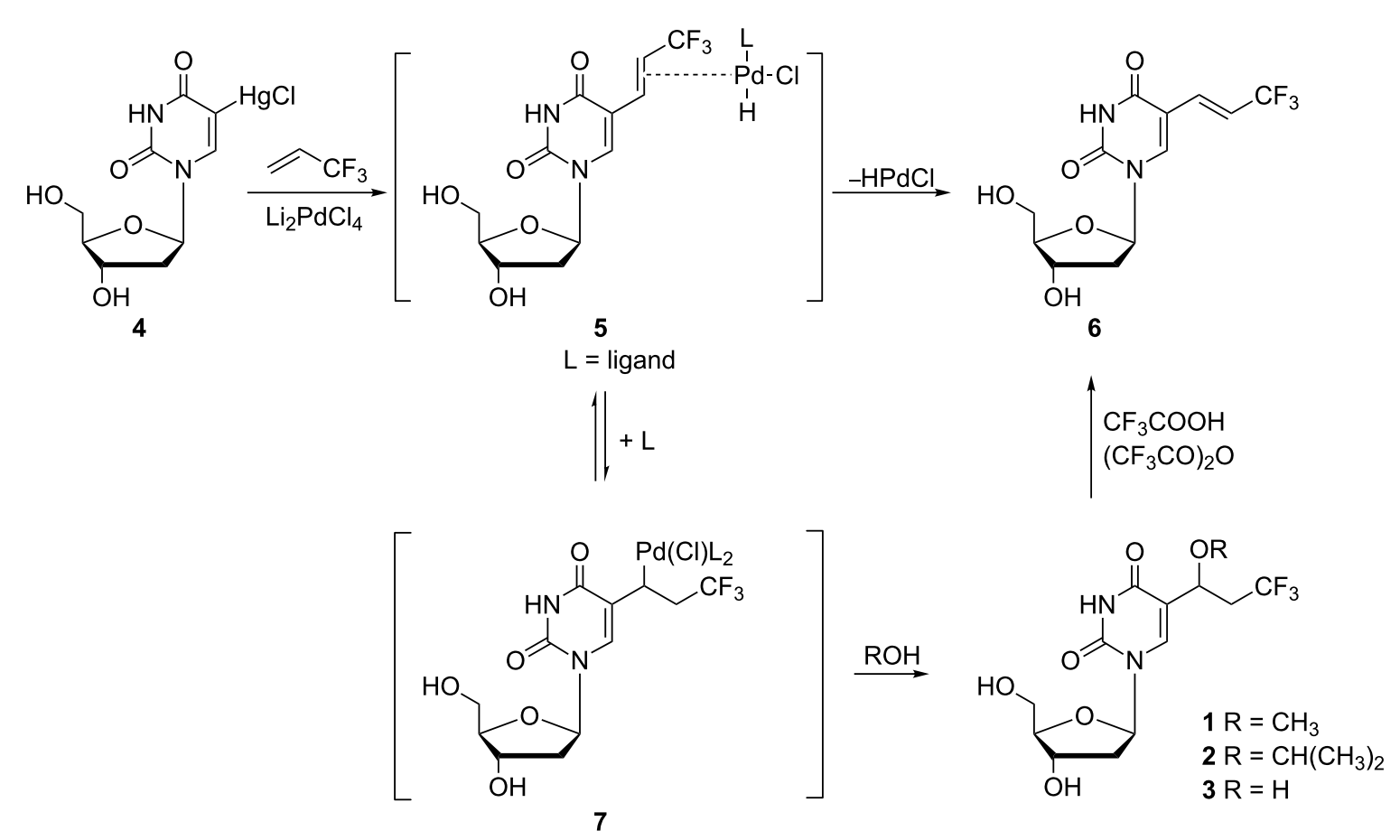

Scheme 1: Synthesis of 5-(3,3,3-trifluoro-1-methoxypropyl)-2'-deoxyuridine (1) and 5-(3,3,3-trifluoro-1-(2-propyloxy)prop-1-yl)-2'-deoxyuridine (2).

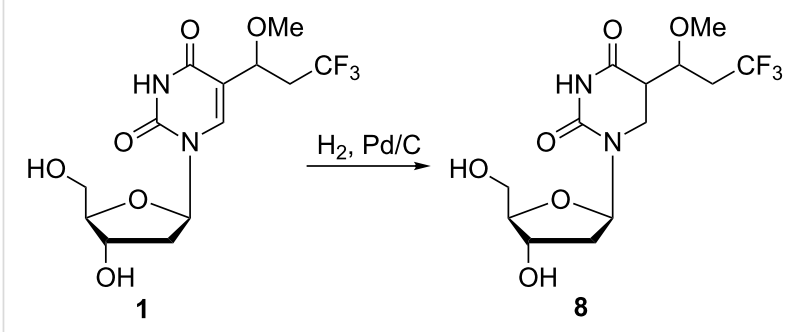

Scheme 2: Synthesis of 5-(3,3,3-trifluoro-1-methoxyprop-1-yl)-5,6dihydro-2'-deoxyuridine (8).

activity. In 1989 Kumar and co-workers reported, amongst other things, two 5-(1-methoxy-2-haloethyl)-2'-deoxyuridines 12 and 13 (Scheme 3) [9].
Their synthesis was based on the addition of $\operatorname{HOX}(\mathrm{X}=\mathrm{Br}, \mathrm{Cl})$ to the vinyl moiety of 5-vinyl-2'-deoxyuridine (9). The reaction was carried out in aqueous dioxane, and hydroxybromoethyl $\mathbf{1 0}$ and hydroxychloroethyl $\mathbf{1 1}$ derivatives were obtained in $70 \%$ and $60 \%$ yields, respectively. Subsequent treatment of hydroxyl derivatives $\mathbf{1 0}$ and $\mathbf{1 1}$ with methanolic sulfuric acid gave the corresponding desired 5-(1-methoxy-2-haloethyl) derivatives 12 and $\mathbf{1 3}$ in 93 and $98 \%$ yields, respectively. No details of the separation method for the two diastereomers were described in their article.

A year later, Kumar and co-workers extended their research to the modification of the sugar portion of nucleosides [10] by preparing the iodomethoxy derivatives of 2'-deoxyuridine $\mathbf{2 8}$, 2'-fluoro-2'-deoxyuridine 29 and uridine 30 (Scheme 4).

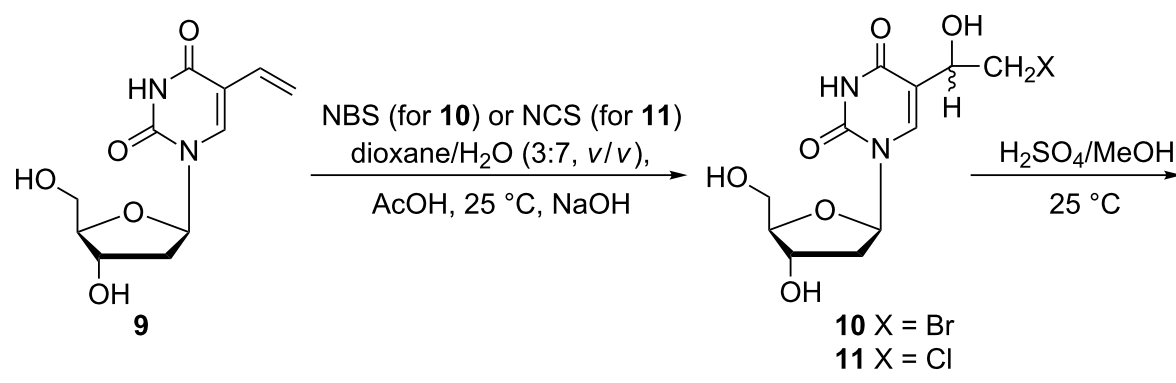<smiles>[X]CC(OC)c1cn(C2COC(CO)C(O)C2)c(=O)[nH]c1=O</smiles>

Scheme 3: Synthesis of 5-(methoxy-2-haloethyl)-2'-deoxyuridines 12 and 13. 


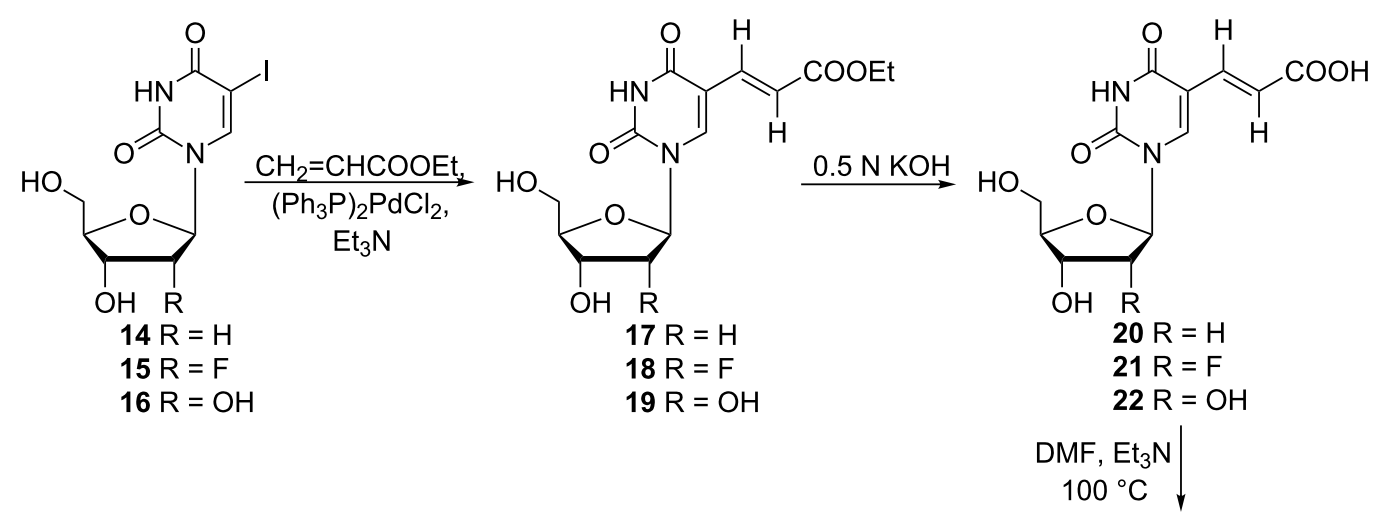<smiles>[R]C1C(O)C(CO)OC1n1cc(C(C)(C)C)c(=O)[nH]c1=O</smiles>

$28 \mathrm{R}=\mathrm{H}$

$29 \mathrm{R}=\mathrm{F}$

$30 \mathrm{R}=\mathrm{OH}$

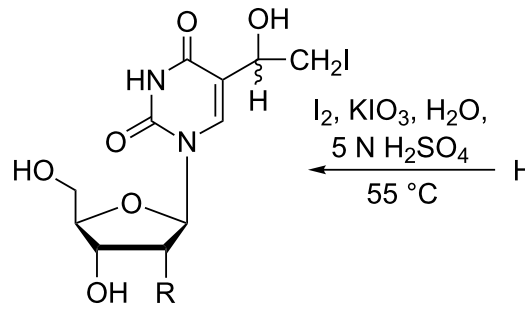

$25 \mathrm{R}=\mathrm{H}$

$26 \mathrm{R}=\mathrm{F}$

$27 \mathrm{R}=\mathrm{OH}$<smiles>[R]C1C(O)C(CO)OC1n1cc(/C=C/[R]([Z])([R])F)c(=O)[nH]c1=O</smiles>

Scheme 4: Synthesis of 5-(1-methoxy-2-iodoethyl) nucleosides 28-30.

The authors utilized the known palladium acetate-triphenylphosphine-catalyzed reaction of 5-iodo-2'-deoxyuridine with vinyl acetate for the preparation of 5-vinyl-2'-deoxyuridine (9) [14]. However, attempts to prepare 2'-fluoro-2'-deoxyuridine $\mathbf{2 3}$ and uridine analogue 24 by this method were unsuccessful. Hence, the 5-vinyl derivatives $\mathbf{9 , 2 3}$ and $\mathbf{2 4}$ were prepared by three-step palladium-catalyzed synthesis of 5-iodo-2'-fluoro2'-deoxyuridine (15) and 5-iodouridine (16) with ethyl acrylate, followed by subsequent alkaline hydrolysis and decarboxylation. Iodination of 5-vinyl analogues 9, 23 and $\mathbf{2 4}$ with iodine in the presence of the iodic acid as an oxidizing agent afforded 5-(1-hydroxy-2-iodoethyl)-2'-deoxyuridine (25, 59\%), 5-(1-hydroxy-2-iodoethyl)-2'-fluoro-2'-deoxyuridine (26, $72 \%)$ and 5-(1-hydroxy-2-iodoethyl)uridine $(27,65 \%)$ as diasteroisomeric mixtures. Finally, treatment of hydroxy derivatives 25-27 with methanolic sulfuric acid gave the desired 5-(1methoxy-2-iodoethyl) nucleosides $\mathbf{2 8}-\mathbf{3 0}$ in $81-94 \%$ yields. All three compounds were obtained as mixtures of two diastereomers.

In order to develop new potential tumor localization agents, Iwashina and co-workers investigated the radiolabelled 5-(1methoxy-2-iodoethyl) nucleoside 31 (Figure 4) [15] which was obtained by radio-iodination of 5-(1-methoxy-2-iodoethyl)-2'deoxyuridine (28) via isotope exchange by the pivalic acid melt method.

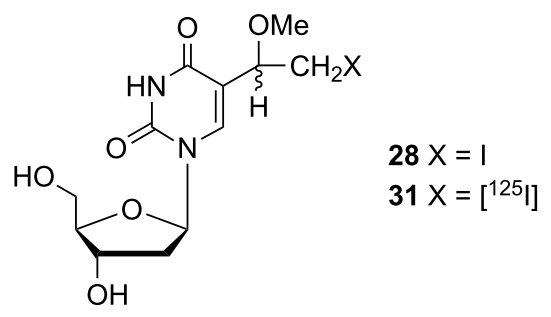

Figure 4: $\left[{ }^{125} \mid\right]$ radiolabelled 5-(1-methoxy-2-iodoethyl)-2'-deoxyuridine 31 .

In addition to the above mentioned 5-(1-methoxy-2-iodoethyl) nucleosides, Kumar and co-workers also reported the synthesis of other alkoxy derivatives - 5-(1-alkoxy-2-iodoethyl) and 5-(1ethoxy-2,2-diiodoethyl)-2'-deoxyuridine analogues 33-36 (Scheme 5) [11]. The reaction of (E)-5-(2-iodovinyl) 32 and 5 -vinyl-2'-deoxyuridine (9) with iodine monochloride and alcohols such as ethanol, 2-fluoroethanol or 2,2,2-trifluoroethanol afforded 5-(1-ethoxy-2,2-diiodoethyl) 33 and 5-(1-alkoxy-2iodoethyl)-2'-deoxyuridines 34-36, in 33-90\% yields. All of these four products $\mathbf{3 3}-\mathbf{3 6}$ were obtained as a mixture of two diastereomers in a $1: 1$ ratio.

In the synthesis of 5-(1-fluoro-2-iodoethyl)-3',5'-di- $O$-acetyl-2'deoxyuridine (37), by-products such as 5-(1-methoxy-2- 


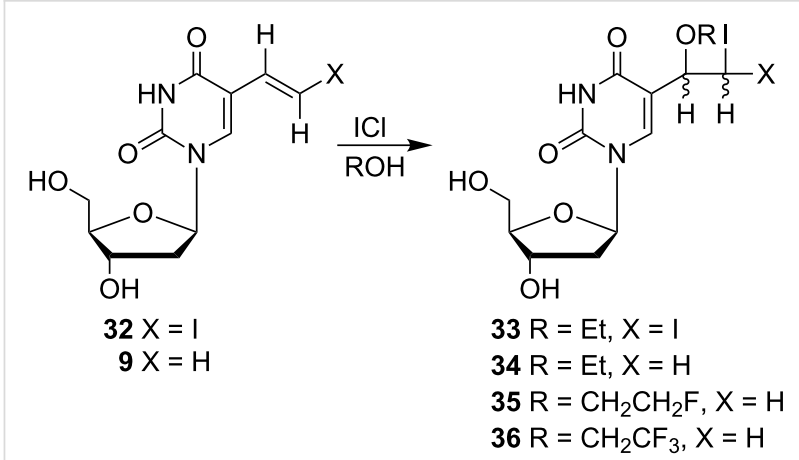

Scheme 5: Synthesis of 5-(1-alkoxy-2-iodoethyl) 34-36 and 5-(1-ethoxy-2,2-diiodoethyl)-2'-deoxyuridine (33).

iodoethyl)-3',5'-di- $O$-acetyl-2'-deoxyuridine (38) and 5-(1-ethoxy-2-iodoethyl)-3',5'-di-O-acetyl-2'-deoxyuridine (39) were identified (Scheme 6) [12]. From the reaction of 5-(1-hydroxy2-iodoethyl)-3',5'-di- $O$-acetyl-2'-deoxyuridine (40) with DAST $\left(\mathrm{Et}_{2} \mathrm{NSF}_{3}\right)$ at $-40{ }^{\circ} \mathrm{C}$ in anhydrous dichloromethane, 5-(1fluoro-2-iodoethyl)-3',5'-di- $O$-acetyl-2'-deoxyuridine (37) as well as 5-(1-methoxy-2-iodoethyl)-3',5'-di-O-acetyl-2'deoxyuridine (38) and 5-(1-ethoxy-2-iodoethyl)-3',5'-di- $O$ acetyl-2'-deoxyuridine (39) were obtained as major products. The authors suggested a mechanism for the formation of methoxy 38 and ethoxy 39 derivatives, which was based on decomposition of 5-(1-fluoro-2-iodoethyl)-3',5'-di-O-acetyl-2'deoxyuridine (37) to carbonium cation intermediates $\mathbf{4 1}$ and $\mathbf{4 2}$ at $25{ }^{\circ} \mathrm{C}$. Subsequent reaction of cation $\mathbf{4 1}$ with methanol, ethanol or water produced the alkoxy derivatives $\mathbf{3 8}$ and $\mathbf{3 9}$. The authors presumed that the nucleosides $\mathbf{3 8}$ and $\mathbf{3 9}$ were formed during the silica gel column chromatography, where a mixture of methanol, chloroform and ethanol was used as eluent.

In addition, the authors described the reaction of the 5-(1hydroxy-2-chloroethyl) 43 and 5-(1-hydroxy-2-bromoethyl)3',5'-di- $O$-acetyl-2'-deoxyuridine (44) with thionyl bromide, which provided 5-(1-ethoxy-2-chloroethyl)-3',5'-di-O-acetyl-2'deoxyuridine (45) and 5-(1-ethoxy-2-bromoethyl)-3',5'-di- $O$ acetyl-2'-deoxyuridine (46) (Figure 5).

The introduction of an additional halogen to the ethyl moiety at the $\mathrm{C}-5$ position of the uracil base led to dihalo derivatives that were also reported by Kumar and co-workers [13]. The required 5-(1-methoxy-2,2-dihaloethyl)-2'-deoxyuridines 47-49 (Scheme 7) were prepared by the addition of $\mathrm{CH}_{3} \mathrm{OX}(\mathrm{X}=\mathrm{Cl}$, $\mathrm{Br}$ or I) to the vinyl moiety of (E)-5-(2-halovinyl)-2'-deoxyuridine.

Rai and co-workers developed an efficient synthesis of 5-[1-(2halo(or nitro)ethoxy)-2-iodoethyl]-2'-deoxyuridines 50-54

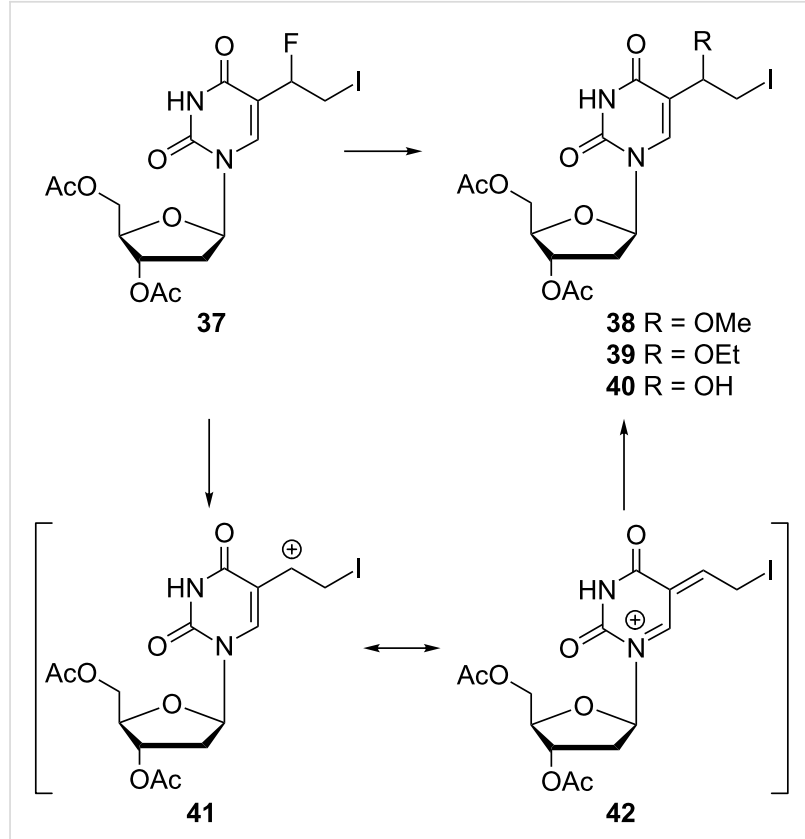

Scheme 6: Synthesis of 5-(1-methoxy-2-iodoethyl)-3',5'-di-O-acetyl-2'deoxyuridine (38) and 5-(1-ethoxy-2-iodoethyl)-3', 5'-di-O-acetyl-2'deoxyuridine (39).

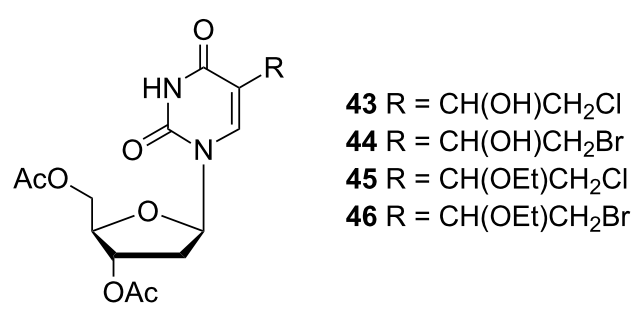

Figure 5: 5-(1-Hydroxy(or ethoxy)-2-haloethyl)-3',5'-di-O-acetyl-2'deoxyuridines 43-46.

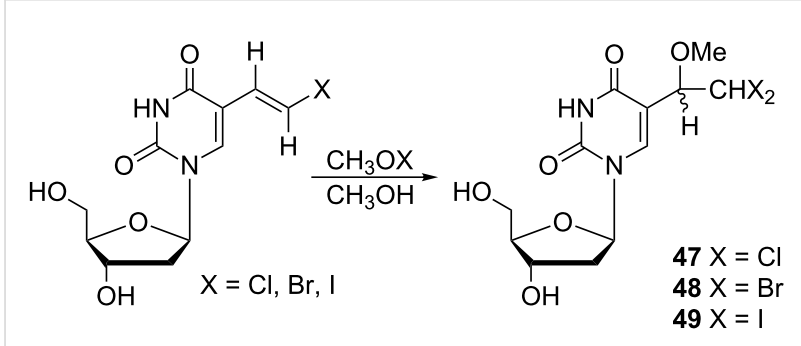

Scheme 7: 5-(1-Methoxy-2,2-dihaloethyl)-2'-deoxyuridines 47-49.

(Scheme 8) and evaluated their antiviral activity [16]. For this purpose, 5-vinyl-2'-deoxyuridine (9) was used as the starting compound. The regiospecific reaction of the 5-vinyl-2'deoxyuridine (9) with iodine monochloride in the presence of various alcohols afforded 2'-deoxynucleosides 50-54 in $24-52 \%$ yield. 


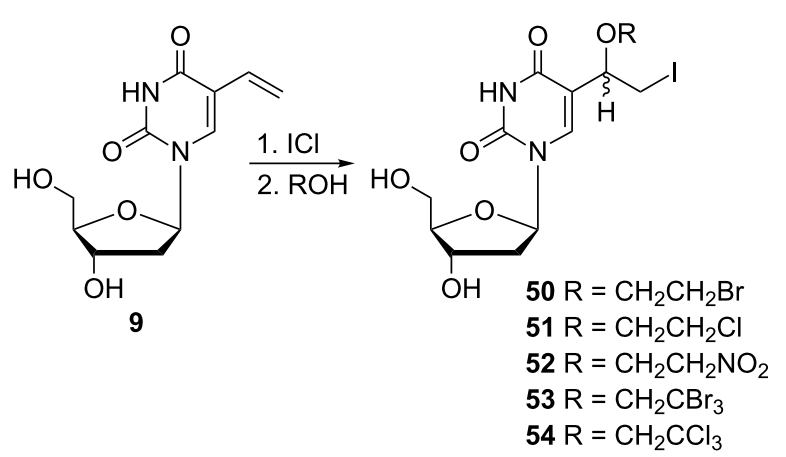

Scheme 8: Synthesis of 5-[1-(2-haloethyl(or nitro)ethoxy)-2-iodoethyl]2'-deoxyuridines $\mathbf{5 0 - 5 4 .}$

Uracil analogues: The syntheses of some of the aforementioned 2'-deoxyuridine analogues were also described for modified uracil derivatives. The first group of these derivatives is represented by alkoxyiodoethyl derivatives 56-59 prepared by the reaction of 5-vinyluracil (55) with iodine monochloride (Scheme 9) [11]. The reaction was carried out in the presence of ethanol, 2-fluoroethanol, 2,2,2-trifluoroethanol or 2,2,2trichloroethanol to give the 5-(1-ethoxy-2-iodoethyl) 56, 5-[1(2-fluoroethoxy)-2-iodoethyl] 57, 5-[1-(2,2,2-trifluoroethoxy)2-iodoethyl] 58 and 5-[1-(2,2,2-trichloroethoxy)-2-iodoethyl] 59 uracil analogues.

Rai and co-workers also used the same procedure to prepare a series of 5-[1-(2-haloethoxy-2-iodoethyl)]uracils 60-61 (Scheme 9) [16]. Thus, regiospecific addition of iodine monochloride in the presence of various alcohols to 5 -vinyluracil (55)

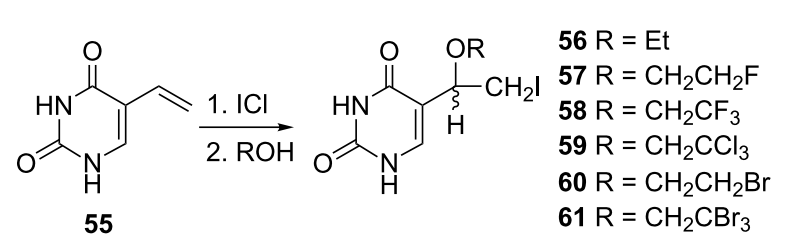

Scheme 9: Synthesis of alkoxyuracil analogues 56-61.

gave 5-[1-(2-bromoethoxy)-2-iodoethyl]uracil (60) and 5-[1(2,2,2-tribromoethoxy)-2-iodoethyl)]uracil (61).

A similar reaction was used 14 years earlier by Kumar and co-workers for the synthesis of 5-(1-methoxy-2-haloethyl)uracils 62-64 (Figure 6) [17] by the addition of $\operatorname{HOX}(\mathrm{X}=\mathrm{Br}$, $\mathrm{Cl}$ ) or $\mathrm{ICl}$ to the 5-vinyluracil (55) and subsequent treatment with methanolic sulfuric acid.

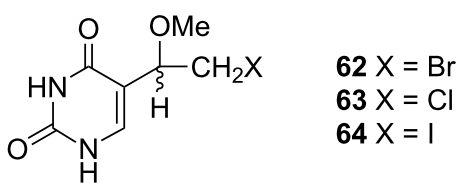

Figure 6: 5-(Methoxy-2-haloethyl)uracils 62-64.

In 2002 Ismail and co-workers published an efficient synthetic route for the preparation of ethoxy-substituted 5-(perfluoroalkyl)pyrimidines (Scheme 10) and investigated their regioselective transformations [18]. Some of these fluorine-containing pyrimidine analogues are potent antitumor and antiviral agents.<smiles>CCOc1ncc(Br)c(OCC)n1</smiles><smiles>CCOc1ncc(CP)c(OCC)n1</smiles><smiles>CC(C)C(CO)[Mg]O</smiles>
$66 n=4$
$67 n=6$

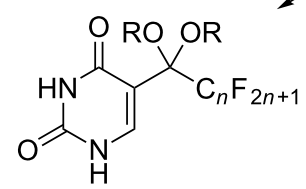
$\mathrm{RONa}$ $63-84 \%$<smiles>O=c1[nH]cc(C(F)(F)F)c(=O)[nH]1</smiles>
$68 n=4$ $69 n=6$

$70 n=3, \mathrm{R}=\mathrm{C}_{2} \mathrm{H}_{5}$

$71 n=5, \mathrm{R}=\mathrm{C}_{2} \mathrm{H}_{5}$

$72 n=3, \mathrm{R}=\mathrm{C}_{6} \mathrm{H}_{5} \mathrm{CH}_{2}$

$73 n=5, \mathrm{R}=\mathrm{C}_{6} \mathrm{H}_{5} \mathrm{CH}_{2}$

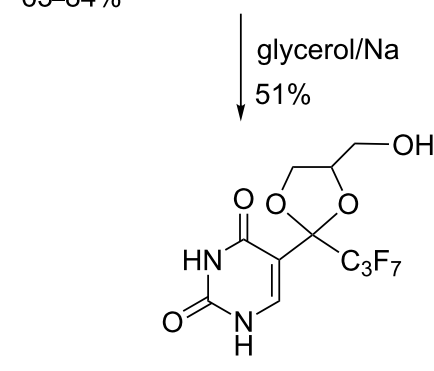


The reported synthesis started with the treatment of 5-bromo2,4-diethoxypyrimidine (65) with either perfluorobutyl or perfluorohexyl iodide in the presence of activated copper bronze in DMSO. This reaction afforded 5-(perfluoroalkyl)pyrimidines 66 and 67 in high yields. Subsequent acid hydrolysis of 66 and 67 provided 5-(perfluoroalkyl)pyrimidines 68 and 69. The latter readily underwent nucleophilic attack by alkoxide ions to yield alicyclic or cyclic acetals $\mathbf{7 0 - 7 3}$ and $\mathbf{7 4}$, respectively, depending on the alcohol used.

Uridine and arabinofuranosyl analogues: 5-Substituted uracil nucleosides where the sugar component is ribose or arabinose have also been prepared. Johar and co-workers described the synthesis of 1- $\beta$-D-arabinofuranosyl-5-(1-methoxy-2iodoethyl)uracil (79) (Scheme 11) in a recent article [19]. The compound was also reported by Kumar and co-workers in 1992 [20].

The synthesis was based on the reaction of $1-\beta-D$-arabinofuranosyl-5-iodouracil (75) with ethyl acrylate in the presence of Pd catalyst and TEA. Subsequent alkaline hydrolysis of $\mathbf{7 6}$ afforded the (E)-5-(2-carboxyvinyl) derivative 77. Decarboxylation of the latter gave 5-vinyl-arabinouridine $\mathbf{7 8}$ which was reacted with iodine in the presence of an oxidizing agent, iodic acid to afford 1- $\beta$-D-arabinofuranosyl-5-(1-hydroxy-2iodoethyl)uracil. Treatment of the hydroxyl derivative with methanolic sulfuric acid gave the required methoxy nucleoside 79.

The regiospecific addition of bromine in methanol to $(E)-5-(2-$ bromovinyl)arabinouridine $\mathbf{8 0}$ and its uridine counterpart $\mathbf{8 1}$ afforded 1- $\beta$-D-arabinofuranosyl-5-(2,2-dibromo-1-methoxyethyl)uracil (82) and the ribo analogue 83 (Scheme 12) [21].

In a search for new antiviral agents, 4 '- $C$-methylpyrimidine nucleosides were synthesized (Scheme 13) and their biological

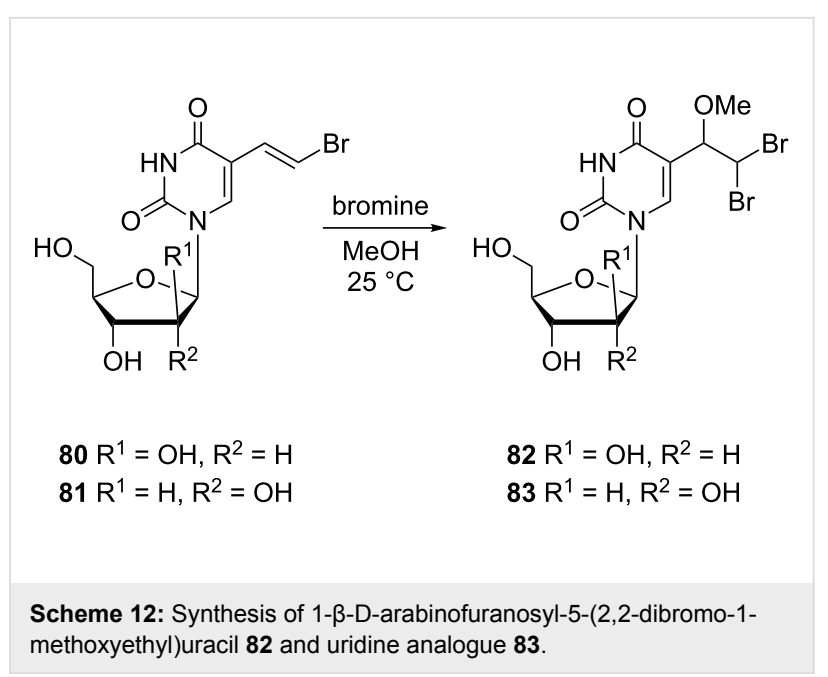

activity evaluated [22]. Firstly, the 4'-C-methyl-D-ribose 84 was prepared by a previously described procedure [23]. Next 5-bromovinyluracil (BVUr) was silylated and reacted with $\mathbf{8 4}$ in the presence of TMSOTf as the Lewis acid. This was followed by deacetylation with anhydrous $\mathrm{K}_{2} \mathrm{CO}_{3}$ in $\mathrm{MeOH}$ to provide the di- $O$-benzylated nucleoside $\mathbf{8 5}$ in $73 \%$ yield. For the change of the configuration at $2^{\prime}-\mathrm{C}$, derivative $\mathbf{8 5}$ was converted to its mesylate and treated with $\mathrm{NaOH}$ in EtOH- $\mathrm{H}_{2} \mathrm{O}$ to afford 4'-Cmethylnucleoside 86 in 58\% yield. Finally, nucleoside 86 was debenzylated with $\mathrm{BBr}_{3}$ in $\mathrm{CH}_{2} \mathrm{Cl}_{2}$ at $-78{ }^{\circ} \mathrm{C}$. On quenching of the reaction with $\mathrm{MeOH}$ the unexpected formation of methoxy derivative 87 was observed, whilst quenching with saturated $\mathrm{NaHCO}_{3}$ solution gave the target derivative $\mathbf{8 8}$.

\section{Synthesis of alkoxy-azidoalkyl derivatives}

In addition to the reactions of $\mathrm{HOX}$ or $\mathrm{CH}_{3} \mathrm{OX}(\mathrm{X}=\mathrm{Cl}, \mathrm{Br}, \mathrm{I})$ with 5-vinyl-2'-deoxyuridine (9), Kumar and co-workers reported the regiospecific addition of halogenocyanamides (X-NHCN) to 9 to produce 5-(1-cyanamido-2-chloroethyl)-2'deoxyuridine (90, Scheme 14) [24].

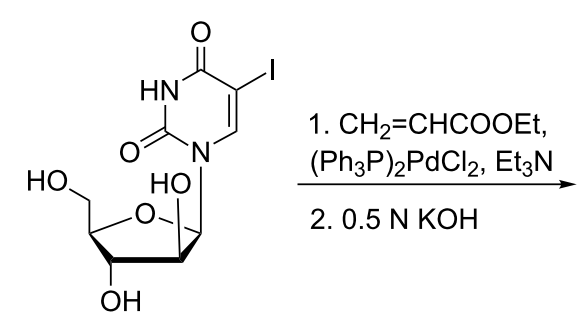

75<smiles></smiles>

79 


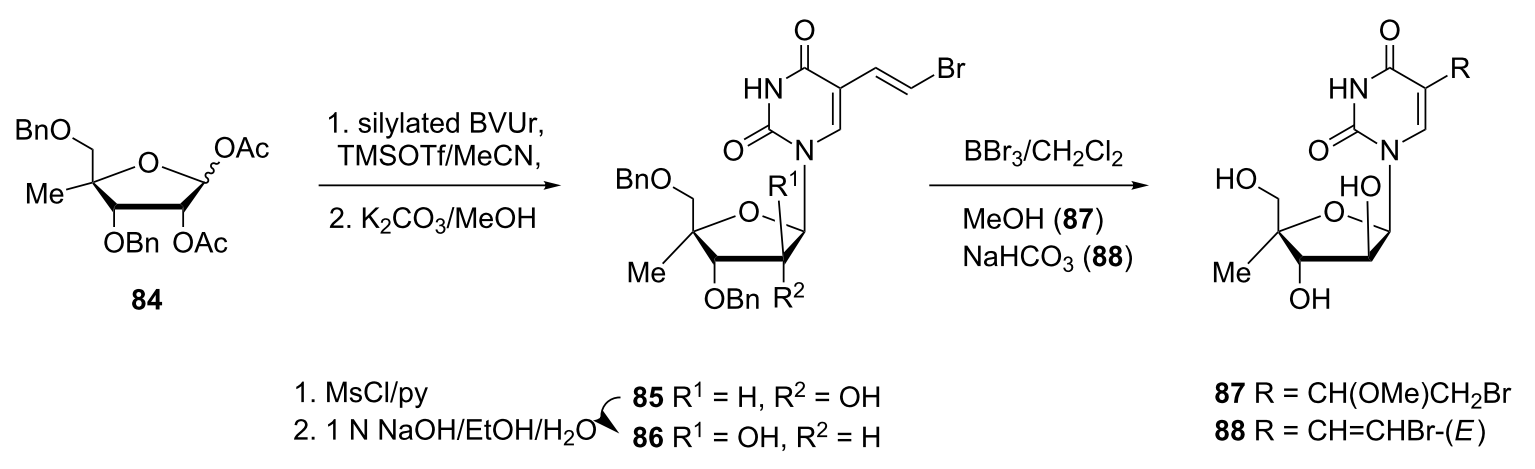

Scheme 13: Synthesis of methoxy derivative 87.<smiles>[R]C(CN)c1cn(C2C[C@H](O)[C@@H](CO)O2)c(=O)[nH]c1=O</smiles>

$91 \mathrm{R}=\mathrm{ONO}_{2}$

$92 \mathrm{R}=\mathrm{OH}$

$93 \mathrm{R}=\mathrm{OCH}_{3}$<smiles></smiles>

$\underset{\mathrm{CH}_{3} \mathrm{CN}, 0-25^{\circ} \mathrm{C}}{\stackrel{\mathrm{NCS}, \mathrm{NH}_{2} \mathrm{CN},}{\longrightarrow}}$

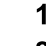

$13 \mathrm{R}=\mathrm{CH}(\mathrm{OMe}) \mathrm{CH}_{2} \mathrm{Cl}$

$89 \mathrm{R}=\mathrm{CH}=\mathrm{CHCl}$

$90 \mathrm{R}=\mathrm{CH}(\mathrm{NHCN}) \mathrm{CH}_{2} \mathrm{Cl}$

Scheme 14: Synthesis of 5-(1-methoxy-2-azidoethyl)-2'-deoxyuridine (93).

In addition to 90 , the reaction of 5-vinyl-2'-deoxyuridine (9) with $\mathrm{N}$-chlorosuccinimide (NCS) and cyanamide was accompanied by the formation of a mixture of by-products such as (E)-5-(2-chlorovinyl)-2'-deoxyuridine (89) and 5-(1methoxy-2-chloroethyl)-2'-deoxyuridine (13). 5-Vinyl-2'deoxyuridine (9) can also undergo reaction with ceric ammonium nitrate (CAN) and sodium azide in aqueous acetonitrile to give 5-(1-hydroxy-2-azidoethyl)-2'-deoxyuridine (92) in $32 \%$ yield. When dry acetonitrile was used as the reaction solvent and the reaction was quenched with methanol, 5-(1methoxy-2-azidoethyl)-2'-deoxyuridine (93) was obtained in $25 \%$ yield.

\section{Synthesis of alkoxy-alkyl derivatives}

The C-5 modified pyrimidine nucleosides with the short alkyl substituent have been at the center of intense interest since the early 1970 s due to their potential chemotherapeutic and antiviral properties. It was reported, for instance, that 5-ethyluracil may undergo incorporation into bacterial DNA [25] and that 5-ethyl-2'-deoxyuridine readily replaces thymidine in bacteriophage DNA [26].
Bergstrom and co-workers also targeted the alkyl modification at position 5 of pyrimidine analogues [27] and synthesized 5-(1methoxyethyl)uridine (96) (Scheme 15) with a view towards transformation of the latter to the 5-ethyl analogue. In their reaction the organomercuri nucleoside 94 was converted to the organopalladium analogue via the reaction with $0.1 \mathrm{M}$ palladium catalyst and ethene in methanol. Surprisingly, the major product of the reaction was the methoxy derivative 96 in 39\% yield instead of the expected 5-vinyluridine (24). Similarly, the 2 -deoxyuridine organomercuri derivative 4 reacted with propene in the presence of $\mathrm{Li}_{2} \mathrm{PdCl}_{4}$ in methanol to give 5-(1methoxypropyl)-2'-deoxyuridine (97) as one of the products but the compound was not separated from the reaction mixture.

5-(1-Methoxyethyl)-2'-deoxyuridine (100) was prepared by Kumar and co-workers. However, they reported a different synthetic route leading to the desired nucleoside 100, which differs from the above mentioned preparation of uridine analogue 96 (Scheme 16) [28]. 5-(1-Methoxy-2-iodoethyl)-2'-deoxyuridine (28) was reacted with hydrogen in the presence of $10 \% \mathrm{Pd} / \mathrm{C}$ in ethanol at $25{ }^{\circ} \mathrm{C}$ to give as the major product 5-(1-methoxy- 


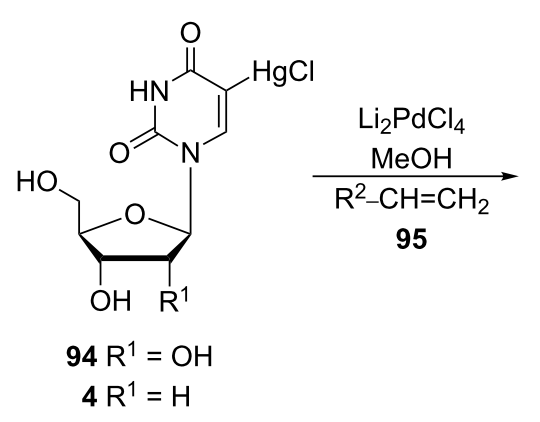<smiles>[R]CC(OC)c1cn(C2OC(CO)C(O)C2[R])c(=O)[nH]c1=O</smiles>

$96 \mathrm{R}^{1}=\mathrm{OH}, \mathrm{R}^{2}=\mathrm{H}$

$97 R^{1}=H, R^{2}=M e$<smiles>[R]C=Cc1cn(C2OC(CO)C(O)C2[R])c(=O)[nH]c1=O</smiles>

$24 \mathrm{R}^{1}=\mathrm{OH}, \mathrm{R}^{2}=\mathrm{H}$

$98 \mathrm{R}^{1}=\mathrm{OH}, \mathrm{R}^{2}=\mathrm{COOMe}$

$99 \mathrm{R}^{1}=\mathrm{OH}, \mathrm{R}^{2}=\mathrm{Ph}$<smiles>CO[C@H](I)c1cn(C2CC(O)C(CO)O2)c(=O)[nH]c1=O</smiles>

28

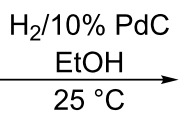

HO<smiles>CO[C@H](C)c1cn(C2CC3OCC2O3)c(=O)[nH]c1=O</smiles>

100<smiles>CCc1cn(C2CC(O)C(CO)O2)c(=O)[nH]c1=O</smiles>

101

Scheme 16: Synthesis of 5-(1-methoxyethyl)-2'-deoxyuridine (100).

ethyl)-2'-deoxyuridine (100) in 26\% yield accompanied by 5-ethyl-2'-deoxyuridine (101) in 13\% yield.

Because of the high activity of (E)-5-(2-bromovinyl)-2'-deoxy4'-thiouridine against HSV-1, HSV-2 and Varicella zoster virus, the group of 2'-deoxy-4'-thionucleosides have been extensively investigated [29]. In this context, a series of 5-substituted 2'-deoxy-4'-thiopyrimidine nucleosides were synthesized by Rahim and co-workers in order to evaluate their antiviral activity [30]. One such compound is 2'-deoxy-5-(1-methoxyethyl)-4'-thiouridine (104) (Scheme 17). The desired methyl ether 103 was obtained by the methylation of 2'-deoxy-3',5'-di$O$ - $p$-toluoyl-5-(1-hydroxymethyl)-4'-thiouridine (102) with methanol in the presence of $p$-toluenesulfonic acid. Subsequent treatment with sodium methoxide gave deprotected thiouridine 104.

Among others, Jones and co-workers focused their attention on alkyl ethers with longer chains [31]. From a study of some chemical properties of 5-vinyluracil, they successfully synthesized 5-(1-butoxyethyl)uracil (105) and 5-(1-butoxyethyl)-2'deoxyuridine (106) (Figure 7). When 2'-deoxy-5-vinyluridine was reacted with butan-1-ol in the presence of trifluoroacetic acid at $55^{\circ} \mathrm{C}$, a mixture of diastereomers of 5-(1-butoxyethyl)$2^{\prime}$-deoxyuridine (106) was obtained. When nearly saturated $\mathrm{HCl}$ in dioxane at $75^{\circ} \mathrm{C}$ was used, only traces of nucleoside $\mathbf{1 0 6}$

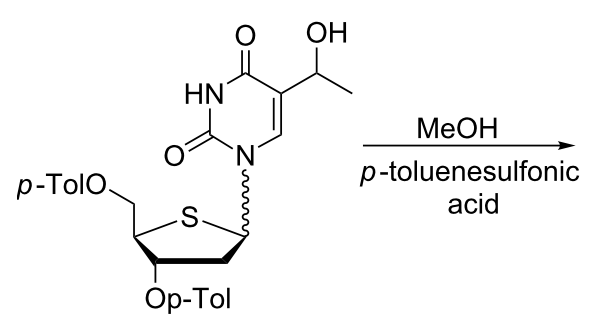

102

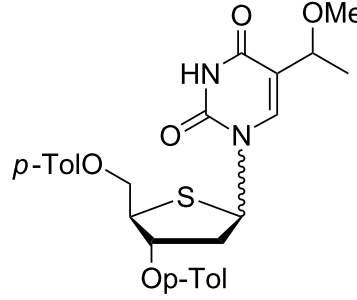

103<smiles>COC(C)c1cn(C[C@@H]2C[C@H](O)[C@H](CO)S2)c(=O)[nH]c1=O</smiles>

104 
<smiles>CCCCOC(C)c1c[nH]c(=O)[nH]c1=O</smiles>

105<smiles>CCCCC(C)c1cn(C2CC(O)C(CO)O2)c(=O)[nH]c1=O</smiles>

106
Figure 7: 5-(1-Butoxyethyl)uracil 105 and 5-(1-butoxyethyl)-2'deoxyuridine (106).

were formed and 5-(1-butoxyethyl)uracil (105) was obtained as a major product.

Other changes at the $\mathrm{C}-5$ position of pyrimidine analogues led to the anomeric 5-alkyl derivatives $\mathbf{1 1 0}$ and 112, which were synthesized in the early 1980s (Scheme 18) [32]. This preparation was based on the condensation of 5-(1-ethoxy-2-methylprop-1-yl)uracil (107) with 2-deoxy-3,5-di-O-toluoyl- $\alpha$-D-ribofuranosyl chloride (108). Initially, the uracil ring was protected by the silylation with hexamethyldisilazane. Subsequently, this modified uracil was reacted with protected 2-deoxyribose in the presence of $\mathrm{SnCl}_{4}$. Finally, protected $\alpha$ - and $\beta$-anomers 111 and 109 were treated with methanolic sodium methoxide to afford the nucleosides $\mathbf{1 1 2}$ and $\mathbf{1 1 0 .}$

\section{Synthesis of acyloxy derivatives}

The substitution at position 5 of the pyrimidine ring by acyloxy moiety provides another group of derivatives. Some of these compounds were synthesized as 1-(tetrahydrofuran-2-yl) pyrimidine analogues [33]. The use of such an atypical furanose ring avoids complications with the protection of hydroxyl groups of 2'-deoxyribose during the development of an appropriate method for acylation of the side chain hydroxyl group. The acyloxy derivatives $\mathbf{1 1 7}$ and $\mathbf{1 1 8}$ were synthesized in only a few steps (Scheme 19).
Firstly, 5-acetyluracil (113) was silylated with hexamethyldisilazane containing trimethylsilyl chloride and the silylated acetyluracil coupled with 2-chlorotetrahydrofuran (114) to afford 5-acetyl-1-(tetrahydrofuran-2-yl)uracil (115). Subsequent reduction of the keto group with sodium borohydride gave 5-(1-hydroxyethyl)-1-(tetrahydrofuran-2-yl)uracil (116). Final acetylation of the hydroxyl group of derivative $\mathbf{1 1 6}$ with acetic anhydride in pyridine afforded 5-(1-acetyloxyethyl)-1(tetrahydrofuran-2-yl)uracil (117), whilst treatment of 116 with pivaloyl chloride in the presence of triethylamine and $N, N$ dimethylaminopyridine gave the pivalate ester $\mathbf{1 1 8}$.

An oxidation of 5-vinyl-2'-deoxyuridine (9) was also studied (Scheme 20) [31]. The authors used $m$-chloroperbenzoic acid as an oxidizing agent and observed its influence on the reactivity of the vinyl substituent in the presence and absence of water. When the reaction is performed in the absence of water an epoxide should be obtained. Nevertheless, the authors instead observed a ring opening. However, the product was not fully characterized. As long as water was used, 2'-deoxy-5-(1,2-dihydroxyethyl)uridine (119) was obtained. This dihydroxy derivative 119 was characterized after the transformation to the acetyl analogue 120 using acetic anhydride in pyridine.

\section{Synthesis of arylderivatives}

The synthesis of 5-[alkoxy-(4-nitrophenyl)methyl]uracils $\mathbf{1 2 4}$ (Scheme 21) has recently been investigated [34]. The authors reported the synthesis of alkoxy derivatives with alkyl chain lengths $\mathrm{C}_{1}-\mathrm{C}_{12}$ whose preparation started with the condensation reaction of uracil and $p$-nitrobenzaldehyde in concentrated hydrochloric acid. Subsequently, the resulting 5-[chloro(4-nitrophenyl)methyl]uracil (123) was reacted with different alcohols to give the corresponding ethers $\mathbf{1 2 4 a}-\mathbf{0}$.

The introduction of a sugar moiety to the selected analogues 124f-i afforded 5-[alkoxy(4-nitrophenyl)methyl]uridines $\mathbf{1 2 6} \mathbf{f}-\mathbf{i}$ and $\mathbf{1 2 7 f - i}$ (Scheme 22) [35]. In a first step, the alkoxy uracils 124 were silylated and then reacted with a protected ribose in

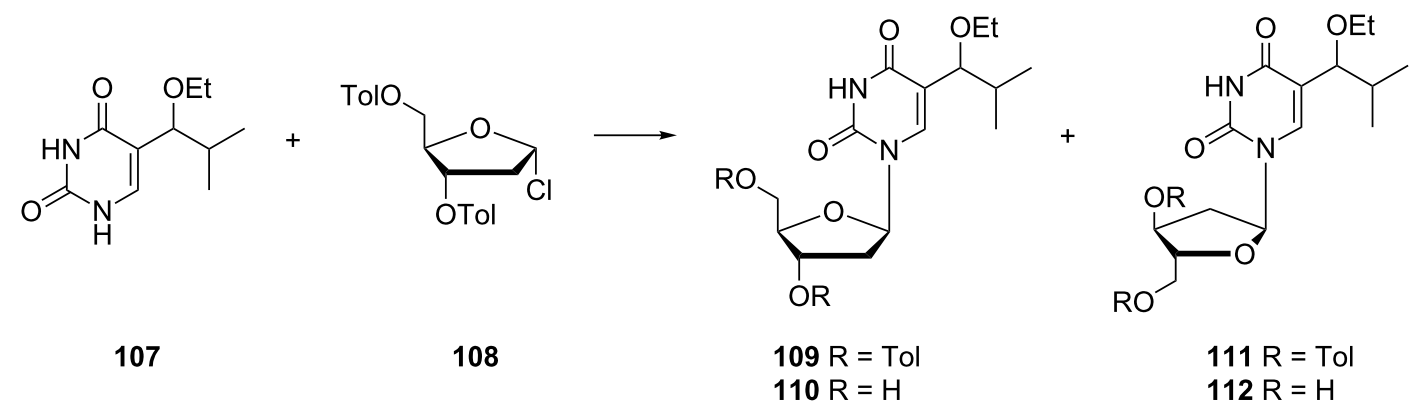


<smiles>CC(=O)c1c[nH]c(=O)[nH]c1=O</smiles>

113

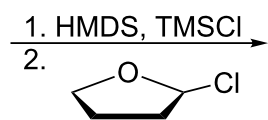

114

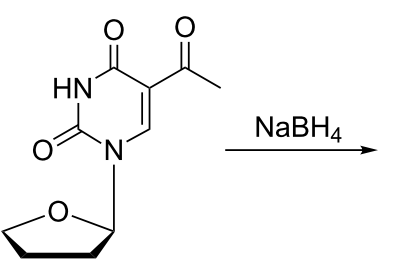

115<smiles>CC(O)c1cn(C2CCCO2)c(=O)[nH]c1=O</smiles>

116 $\left(\mathrm{CH}_{3} \mathrm{CO}\right)_{2} \mathrm{O}$ pyridine<smiles>CC(=O)OC(C)c1cn(C2CCCO2)c(=O)[nH]c1=O</smiles>

117

Scheme 19: Synthesis of 5-(1-acyloxyethyl)-1-(tetrahydrofuran-2-yl)uracils 117 and 118.

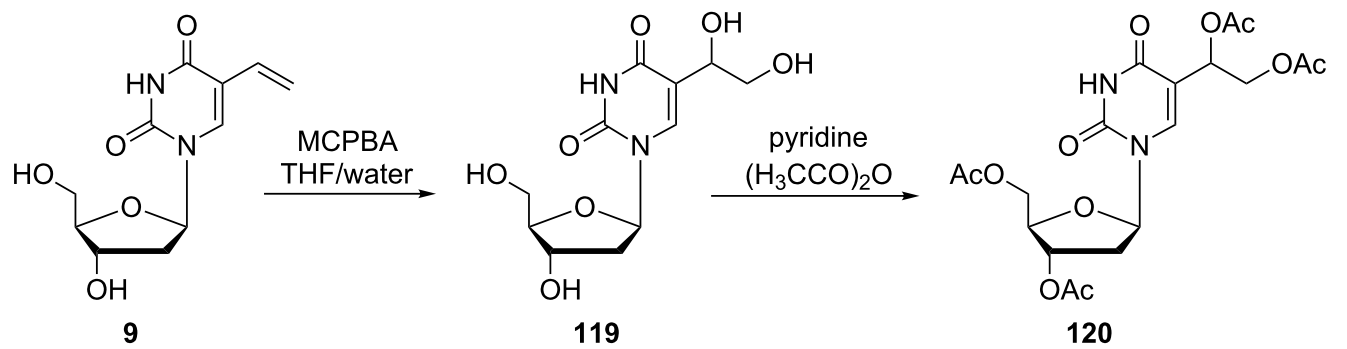

Scheme 20: Synthesis of 5-(1,2-diacetoxyethyl)-3',5'-di-O-acetyl-2'-deoxyuridine 120.<smiles>O=c1cc[nH]c(=O)[nH]1</smiles>

121<smiles>O=Cc1ccc([N+](=O)[O-])cc1</smiles>

122<smiles>[CH]=C</smiles>

e) $\mathrm{R}=\left(\mathrm{CH}_{2}\right)_{4} \mathrm{CH}_{3}$

f) $\mathrm{R}=\left(\mathrm{CH}_{2}\right)_{5} \mathrm{CH}_{3}$

g) $\mathrm{R}=\left(\mathrm{CH}_{2}\right)_{6} \mathrm{CH}_{3}$

h) $\mathrm{R}=\left(\mathrm{CH}_{2}\right)_{7} \mathrm{CH}_{3}$<smiles>O=c1[nH]cc(C(Cl)c2ccc([N+](=O)[O-])cc2)c(=O)[nH]1</smiles>

123<smiles>[R]OC(c1ccc([N+](=O)[O-])cc1)c1c[nH]c(=O)[nH]c1=O</smiles>

124
i) $\mathrm{R}=\left(\mathrm{CH}_{2}\right)_{8} \mathrm{CH}_{3}$
j) $\mathrm{R}=\left(\mathrm{CH}_{2}\right)_{9} \mathrm{CH}_{3}$
k) $\mathrm{R}=\left(\mathrm{CH}_{2}\right)_{10} \mathrm{CH}_{3}$
l) $\mathrm{R}=\left(\mathrm{CH}_{2}\right)_{11} \mathrm{CH}_{3}$

m) $R=i P r$

n) $R=s-B u$

o) $\mathrm{R}=t-\mathrm{Bu}$ 


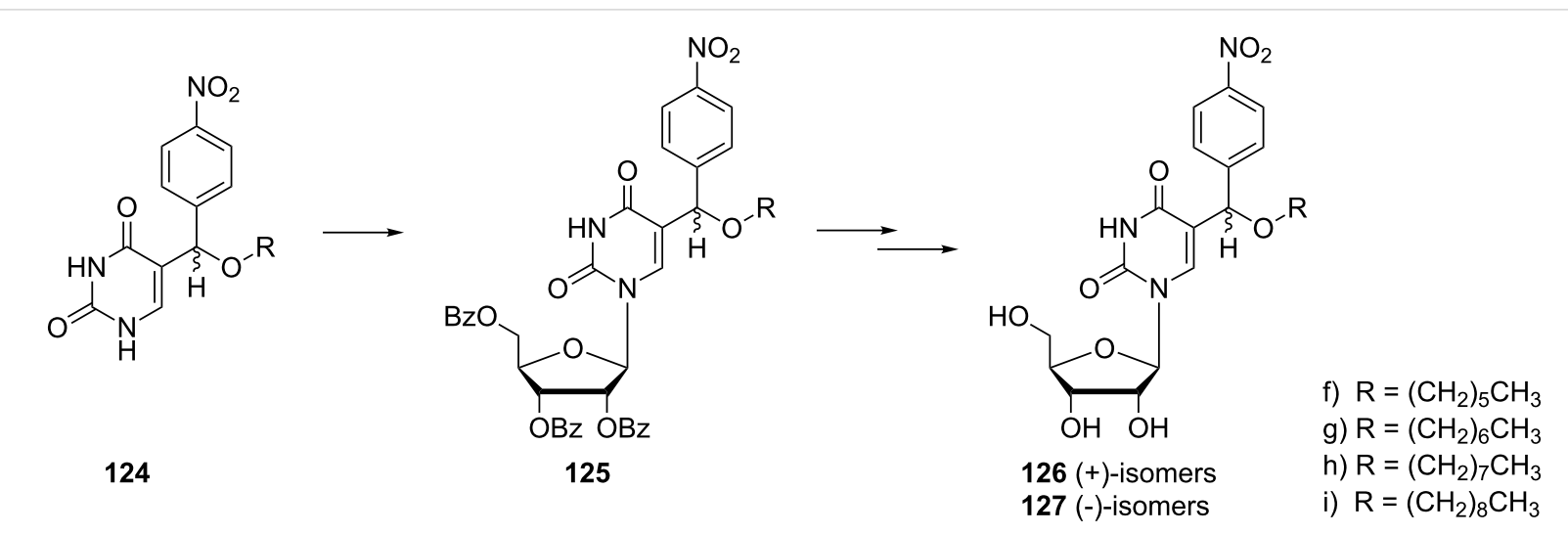

Scheme 22: Synthesis of 5-[alkoxy-(4-nitrophenyl)methyl]uridines 126 and 127.

the presence of TMSOTf to afford diastereomeric mixtures of nucleosides 125. Diasteroisomers were separated and finally treated with methanolic ammonia to afford nucleosides $\mathbf{1 2 6}$ and 127.

\section{Synthesis of oligonucleotide intermediates}

Modified oligonucleotides are powerful tools in nucleic acid research and their synthesis has become an important aspect of bioorganic and medicinal chemistry. One part of oligonucleotide chemistry associated with this review is focused on the studies of the action of 5-formyl-2'-deoxyuridine, which is one of the oxidative thymidine lesions of DNA formed by ionizing radiation. Consequently, several methods for the preparation of appropriate intermediates for the synthesis of oligodeoxynucleotides containing 5-formyl-2'-deoxyuridine have been published. Sugiyama and co-workers reported a seven-step synthesis of phosphoramidite 134 (Scheme 23, reac- tion conditions 1 ) starting with readily available 5-iodo-2'deoxyuridine (14) [36]. The first two steps of the synthesis involved the protection of 3',5'-dihydroxyl groups with the TBDMS group followed by a Pd-catalyzed coupling reaction with vinyl acetate to give the protected 5-vinyluridine $\mathbf{1 2 9}$ in $68 \%$ yield. Oxidation with $\mathrm{OsO}_{4}$ with subsequent acetylation with acetic anhydride in pyridine gave nucleoside 131. The target phosphoramidite $\mathbf{1 3 4}$ was obtained after the standard phosphoramidite synthesis starting with the protection of the 5'-OH group with dimethoxytrityl chloride and final phosphitylation.

Later, Kittaka and co-workers reported the synthesis of phosphoramidite 134 under different conditions [37]. The protected 5-iodo-2'-deoxyuridine $\mathbf{1 2 8}$ was subjected to a Stille coupling reaction with tributyl(vinyl)tin using $\mathrm{Pd}\left(\mathrm{MeCN}_{2} \mathrm{Cl}_{2}\right.$ as a catalyst (Scheme 23, reaction conditions 2). This coupling<smiles>[R20]CC1(O)CC2OC1CC2n1cc([R1])c(=O)[nH]c1=O</smiles>

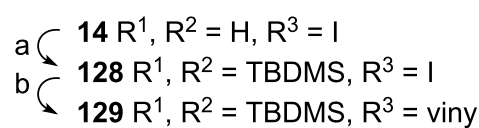

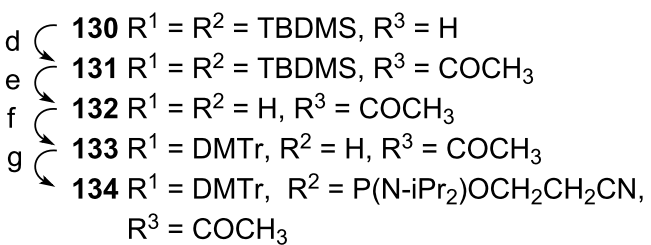

Scheme 23: Synthesis of phosphoramidite 134. Reaction conditions 1: (a) TBDMSCl, imidazole, pyridine, $33 \mathrm{~h}, 99 \%$; (b) vinyl acetate, $\mathrm{Pd}(\mathrm{OAc})_{2}$, $\mathrm{PPh}_{3}, \mathrm{Et}_{3} \mathrm{~N}, \mathrm{DMF}, 70{ }^{\circ} \mathrm{C}, 16 \mathrm{~h}, 68 \%$; (c) OsO $\mathrm{O}_{4}$, 4-methylmorpholine- $\mathrm{N}$-oxide, acetone $\mathrm{H}_{2} \mathrm{O} t-\mathrm{BuOH}(4: 1: 1), 15 \mathrm{~h}, 44 \%$; (d) Ac $2 \mathrm{O}, \mathrm{pyridine}, 44 \mathrm{~h}, 96 \%$; (e) TBAF, THF, $14 \mathrm{~h}, 75 \%$; (f) DMTrCl, DMAP, $\mathrm{Et}_{3} \mathrm{~N}$, pyridine, $22 \mathrm{~h}, 78 \%$; (g) [(iPr) ${ }_{2} \mathrm{~N}_{2} \mathrm{POCH}_{2} \mathrm{CH}_{2} \mathrm{CN}$, tetrazole, $2.5 \mathrm{~h}$, quant. Reaction conditions 2 : (a) TBDMSCl, imidazole, DMF, over night; (b) $5 \mathrm{~mol} \% \mathrm{Pd}\left(\mathrm{MeCN}_{2} \mathrm{Cl}_{2}, \mathrm{Bu}_{3} \mathrm{SnCH}=\mathrm{CH}_{2}\right.$ (1.5 equiv), $\mathrm{MeCN}, 80^{\circ} \mathrm{C}$; (c) cat. OsO ${ }_{4}, \mathrm{NMO}(2.5 \mathrm{equiv}$ ), acetone $\mathrm{H}_{2} \mathrm{O} t$-BuOH (4:1:1); (d) $\mathrm{Ac}_{2} \mathrm{O}$ (4 equiv), pyridine; (e) TBAF (3 equiv), AcOH (2 equiv), THF; (f) DMTrCl (1.5 equiv), pyridine; (g) $\left[(\mathrm{Pr})_{2} \mathrm{~N}_{2} \mathrm{POCH}_{2} \mathrm{CH}_{2} \mathrm{CN}\right.$ (1.8 equiv), DCl (0.7 equiv), $\mathrm{MeCN} \mathrm{CH}_{2} \mathrm{Cl}_{2}$ (1:10). 
reaction was followed by the oxidation of the vinyl group of nucleoside 129 by $\mathrm{OsO}_{4}$ and acetylation of vicinal diol 130 . After deprotection of the 3',5'-hydroxyl groups, the 5'-hydroxyl group was dimethoxytritylated and the 3'-hydroxyl group phosphitylated to afford phosphoramidite 134. The final phosphoramidite $\mathbf{1 3 4}$ was incorporated into oligodeoxynucleotide sequences via solid-phase synthesis by an automated DNA synthesizer.

Modified oligonucleotides can also serve as a tool for the investigation of interactions between $\mathrm{NF}-\kappa \mathrm{B}$ proteins $(\mathrm{NF}-\kappa \mathrm{B}$ is a protein complex that controls the transcription of DNA and plays a key role in regulating the immune response to infection). A study was reported by Kittaka and co-workers [38] which described an interaction between the above noted proteins and modified oligonucleotides, in which thymidine is replaced by a 5-formyl derivative. A phosphoramidite $\mathbf{1 4 5}$ for oligonucleotide synthesis was prepared from $O^{2}-2$-cyclouridine (135) by a multistep synthesis (Scheme 24). In a first step, $O^{2}-2$-cyclouridine (135) was selectively methylated at the $2 '-O$ atom and subsequently iodinated at position 5 with $\mathrm{CAN}-\mathrm{I}_{2}$ in $\mathrm{AcOH}$ to give nucleoside $\mathbf{1 3 7}$ in 74\% yield. Protection of 3',5'diol 137 by TBDMS groups (quantitative) afforded nucleoside 138 which was subsequently subjected to a Stille coupling reaction with tributyl(vinyl)tin using $\mathrm{Pd}\left(\mathrm{CH}_{3} \mathrm{CN}\right)_{2} \mathrm{Cl}_{2}$ as a catalyst followed by oxidation with $\mathrm{OsO}_{4} / \mathrm{NMO}$ to afford the dihydroxy derivative $\mathbf{1 4 1}$ in $77 \%$ yield after two steps. The desired phosphoramidite $\mathbf{1 4 5}$ was obtained in $90 \%$ yield after acetylation of the vicinal diol 141, selective deprotection of 3',5'hydroxyl groups (143 in 96\% yield), dimethoxytritylation of the 5'-hydroxyl group (144 in 89\% yield) and finally, 3'-Ophosphitylation.
An aryl moiety containing phosphoramidite, oligonucleotide 146 (Figure 8), was synthesized by Ding and co-workers and described its utilization of as a hole migration probe [39]. This compound should serve as a molecular probe that facilitates selective detection of excess electron transfer or hole migration in DNA using gel electrophoresis.

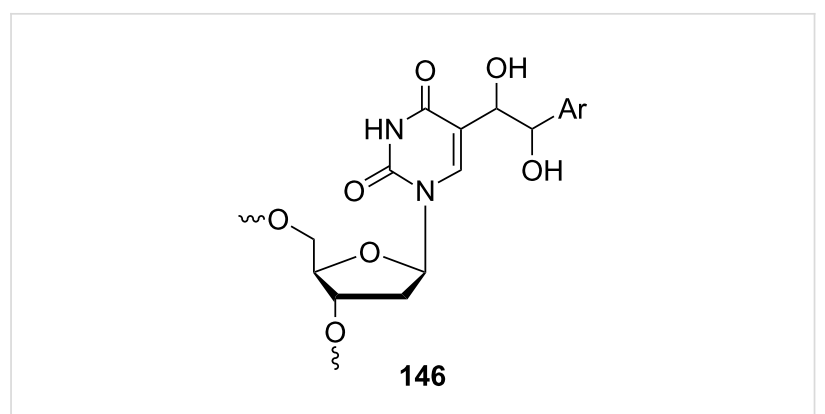

Figure 8: Oligonucleotide 146.

The synthesis of the desired phosphoramidite 150 (Scheme 25) started with the Pd-catalyzed cross-coupling of 5-iodo-2'deoxyuridine (14) and a styrene to afford nucleoside 147 . The oxidation of alkene function in $\mathbf{1 4 7}$ with $\mathrm{OsO}_{4}$ led to a mixture of diastereomers of vicinal diols $\mathbf{1 4 8}$. For the introduction of the oligodeoxynucleotide 146, the dihydroxynucleoside 147 was converted to the corresponding phosphoramidite. This was carried out as follows. First, the hydroxyl groups of deoxyribofuranosyl moiety were silylated to give the protected nucleoside 149 which was then oxidized with $\mathrm{OsO}_{4}$ to afford the protected vicinal diol. The free hydroxyl groups attached to the side chain at position 5 of the uracil ring were acetylated and the silyl protection groups at the sugar ring were removed by

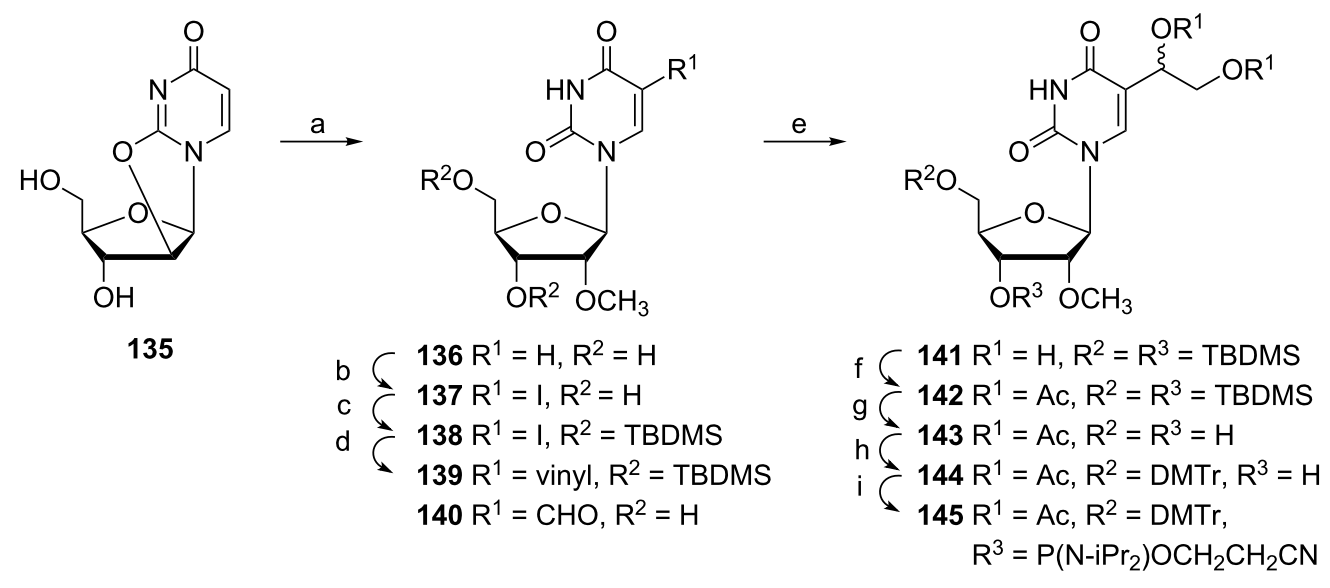

Scheme 24: Synthesis of phosphoramidite 145. (a) $\mathrm{B}\left(\mathrm{OCH}_{3}\right)_{3}, \mathrm{CH}\left(\mathrm{OCH}_{3}\right)_{3}, \mathrm{Na}_{2} \mathrm{CO}_{3}, \mathrm{MeOH}, 150{ }^{\circ} \mathrm{C}$; (b) $\mathrm{I}_{2},(0.6$ equiv), $\mathrm{CAN}(0.5$ equiv), $\mathrm{AcOH}$,

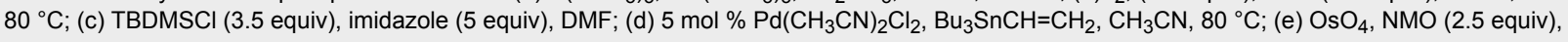
acetone $\mathrm{H}_{2} \mathrm{O} t$-BuOH (4:1:1); (f) $\mathrm{Ac}_{2} \mathrm{O}$ (4 equiv), pyridine; (g) TBAF (2 equiv), AcOH (2 equiv), THF; (h) DMTrCl (1.5 equiv), pyridine; (i) $\left[(\mathrm{Pr})_{2} \mathrm{~N}_{2} \mathrm{POCH}_{2} \mathrm{CH}_{2} \mathrm{CN}\right.$ (1.8 equiv), $\mathrm{DCl}$ (0.7 equiv), $\mathrm{CH}_{3} \mathrm{CN} \mathrm{CH} \mathrm{Cl}_{2}$ (1:10). 


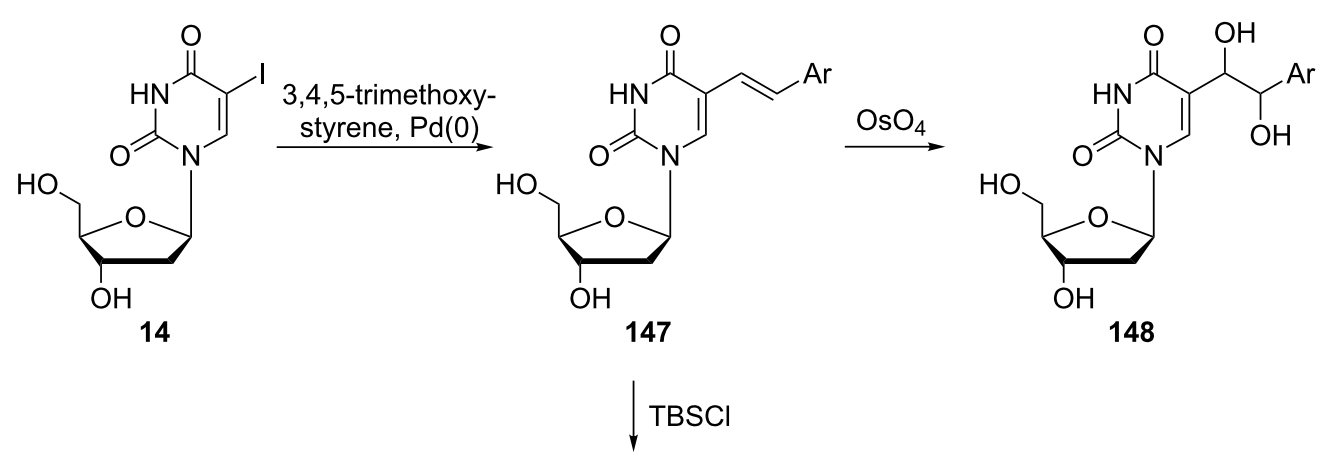

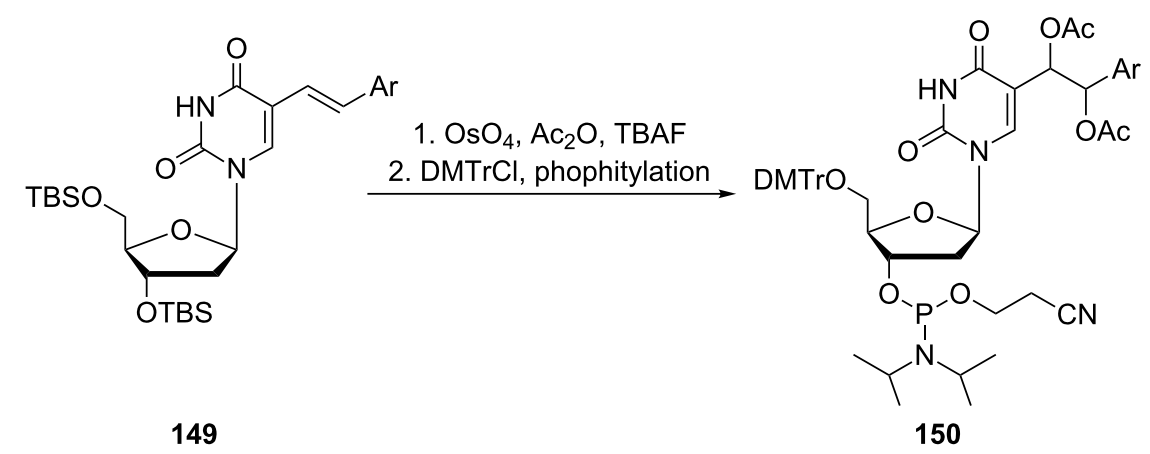

Scheme 25: Synthesis of phosphoramidite 150.

the reaction with TBAF. Finally, the 5'-hydroxyl groups were tritylated and the 3'-hydroxy group converted to the corresponding phosphoramidite 150. The resulting phosphoramidite was incorporated into a 12-mer oligodeoxynucleotide via automated solid-phase synthesis.

\section{Synthesis of bis heterocyclic derivatives}

Sarfati and co-workers published an interesting and facile synthesis of C-5 alkylated 2'-deoxyuridine and uridine derivatives [40]. The C-5 position can be substituted by glycosides of either 2 -acetamido-2-deoxy- $\beta$-D-glucopyranose or $\alpha$-D-mannopyranose. All the products 151-154 (Figure 9) were formed as by-products of the palladium catalyzed addition reaction of alkenes to C-5-mercuriated deoxyuridines.
The synthesis of derivatives $\mathbf{1 5 1}$ and $\mathbf{1 5 2}$ started with condensation reactions of alkenes 155 and 156 with 5-chloromercuri2 -deoxyuridine 4 in the presence of a palladium catalyst (Scheme 26).

The vinyl derivatives 157 and $\mathbf{1 5 8}$ were obtained as major products. However, methoxy derivatives 151 and 152 were produced in modest yields. The monophosphate derivatives 153 and 154 were formed by a similar reaction with mercuriated 2'-deoxyuridine monophosphates.

Almost 10 years earlier, Bergstrom and co-workers published a synthesis based on the same reaction - the Heck cross-coupling reaction of an alkene with an organometallic derivative [41] in<smiles>[R]CCCCCCNC(=O)CC(OC)c1cn(C2CC(O)C(CO)O2)c(=O)[nH]c1=O</smiles><smiles>[R]CCCCCCNC(=O)CC(OC)c1cn(C2CC(O)C(COP(=O)=O)O2)c(=O)[nH]c1=O</smiles>

Figure 9: 2'-Deoxyuridine derivatives 151-154. 

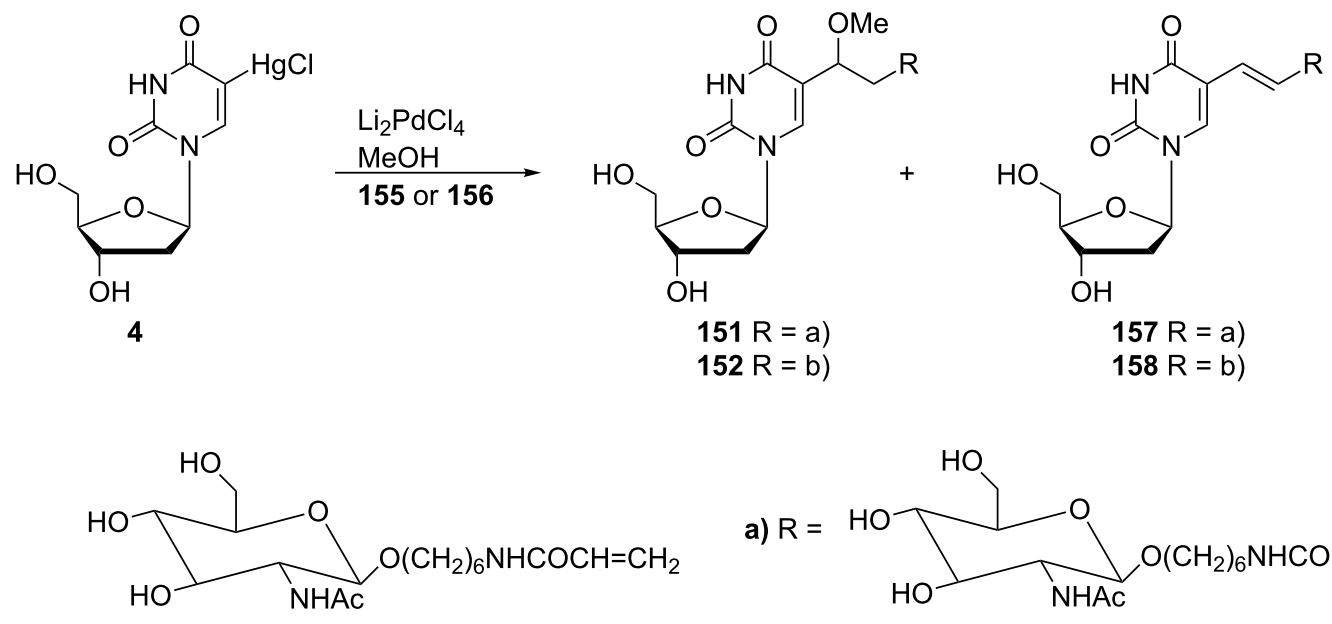

155

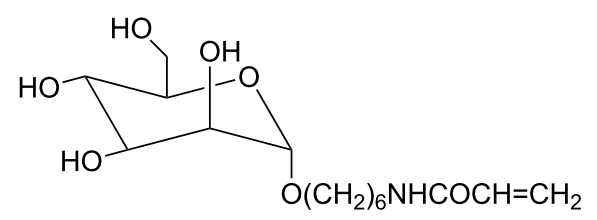

b) $\mathrm{R}=\mathrm{HO}$

156

Scheme 26: Synthesis of 2'-deoxyuridine derivatives 151-152.

which two pyrimidine nucleosides were coupled (Scheme 27). Thus, 5-(chloromercuri)-2'-deoxyuridine was converted to its reactive palladium intermediate $\mathbf{1 5 9}$ by the reaction with $20 \mathrm{~mol} \%$ of $\mathrm{Li}_{2} \mathrm{PdCl}_{4}$ in methanol. Consequently, allyl chloride reacted with this intermediate 159 and gave $(E)-5$-[3-(2'deoxyuridin-5-yl)-1-propen-1-yl]-2'-deoxyuridine (162) as a major product with 5-[3-(2'-deoxyuridin-5-yl)-1-methoxyprop1-yl]-2'-deoxyuridine (163) as a byproduct.

\section{Synthesis of metallocenonucleosides}

The first "metallocenonucleosides" were synthesized and characterized by Meunier and co-workers in 1991 [42]. The term<smiles>[R7]n1cc(CC(Cc2cn([R7])c(=O)[nH]c2=O)P(C)(C)(C)C)c(=O)[nH]c1=O</smiles>

160

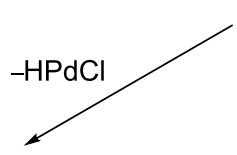

161<smiles>[R]n1cc(/C=C/Cc2cn([R]([H])=O)c(=O)[nH]c2=O)c(=O)[nH]c1=O</smiles>

162<smiles>[R]On1cc(CCC(OC)c2cn([Tl])c(=O)[nH]c2=O)c(=O)[nH]c1=O</smiles>

163 
"metallocenonucleosides" was derived from nucleosides containing a metallocene moiety and these compounds were prepared in order to study their chemical as well as cytotoxic properties (Scheme 28). The reported work was focused on a group of nucleosides with the formula: a) $\mathrm{Ns}-\mathrm{CH}=\mathrm{CH}-\mathrm{Fc}$ or b) $\mathrm{Ns}-\mathrm{CH}_{2}-\mathrm{CH}_{2}-\mathrm{Fc}$, where $\mathrm{Ns}$ (= nucleoside) is either uridine (derivatives 168, 169) or 2'-deoxyuridine (derivatives 165, 166), and $\mathrm{Fc}$ is the abbreviation of ferrocene of molecular formula $\mathrm{C}_{5} \mathrm{H}_{4} \mathrm{FeC}_{5} \mathrm{H}_{5}$. From the reaction of 5-(chloromercuri)-nucleosides 4 or 94 with ethenylferrocene, methoxyderivatives 164 or 167 were also formed along with nucleosides $165,166,168$ and 169.

\section{Synthesis of pseudouridines}

Pseudouridine is a $C$-glycoside isomer of uridine and plays an important role in proteosynthesis. In organisms, pseudouridine is biosynthesized from uridine via the action of pseudouridine synthases. Nevertheless, the specific role of pseudouridines is still the subject of much research. In order to study pseudouridine analogues, many pseudouridine derivatives have been synthesized since 1961 [43-46]. Whilst all of these works achieved the synthesis of pseudouridines, the yields were not quite satisfactory. As late as 1971, Lerch and co-workers established reaction conditions and published advanced studies on the synthesis of pseudouridine (Scheme 29) [47]. Thus, 2,4-ditert-butoxypyrimidin-5-yllithium (170) was reacted with 2,4:3,5-di-O-benzylidene-aldehydo-D-ribose (171) in tetrahydrofuran to afford a mixture of allo and altro isomers of 5-(2,4:3,5-di-O-benzylidene-D-pentahydroxypentyl)-2,4-di-tertbutoxy-pyrimidine 172 and 173, respectively. A complete separation using preparative TLC afforded the allo isomer $\mathbf{1 7 2}$ in $25 \%$ yield and the altro isomer 173 in $37 \%$ yield.

Subsequent cyclization of both isomers in hydrochloric acid gave $\alpha$ - and $\beta$-furanose forms of pseudouridine 174 and $\mathbf{1 7 5}$, respectively (Figure 10). Other studies on the synthesis of pseudouridine analogues were made by Lee and co-workers 20 years later [48]. The 5'-modified pseudouridine 176 and secopseudouridines 177 and 178 were prepared via the ring cleavage of the sugar moiety (Figure 11).<smiles>[R]c1cn(C2OC(CO)C(O)C([R])C2O)c(=O)[nH]c1=O</smiles>

$$
\begin{array}{rl}
4 \mathrm{R}^{1}=\mathrm{H} & 164 \mathrm{R}^{1}=\mathrm{H}, \mathrm{R}^{2}=\mathrm{CH}(\mathrm{OMe}) \mathrm{CH}_{2} \mathrm{Fc} \\
94 \mathrm{R}^{1}=\mathrm{OH} & 165 \mathrm{R}^{1}=\mathrm{H}, \mathrm{R}^{2}=\mathrm{CH}=\mathrm{CH}-\mathrm{Fc} \\
166 \mathrm{R}^{1}=\mathrm{H}, \mathrm{R}^{2}=\mathrm{CH}_{2} \mathrm{CH}_{2} \mathrm{Fc} \\
167 \mathrm{R}^{1}=\mathrm{OH}, \mathrm{R}^{2}=\mathrm{CH}(\mathrm{OMe}) \mathrm{CH}_{2} \mathrm{Fc} \\
168 \mathrm{R}^{1}=\mathrm{OH}, \mathrm{R}^{2}=\mathrm{CH}=\mathrm{CH}-\mathrm{Fc} \\
169 \mathrm{R}^{1}=\mathrm{OH}, \mathrm{R}^{2}=\mathrm{CH}_{2} \mathrm{CH}_{2} \mathrm{Fc}
\end{array}
$$

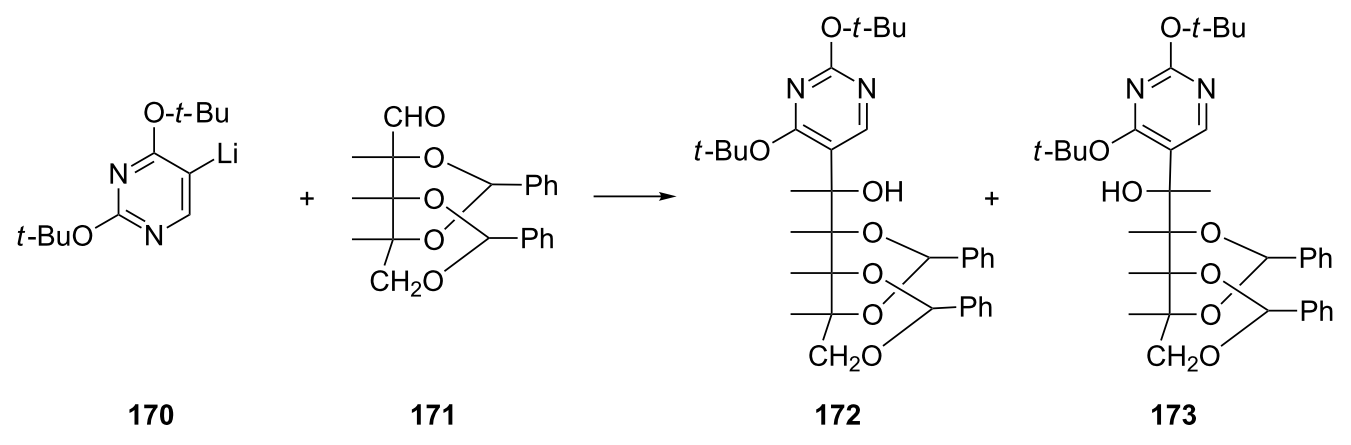




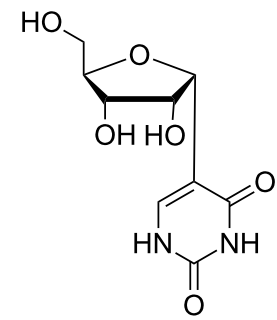

174

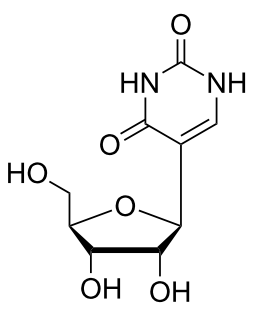

175
Figure 10: $\alpha$ - and $\beta$-pseudouridine (174 and 175).<smiles>NCC(O)C(O)C(O)c1c[nH]c(=O)[nH]c1=O</smiles>

176<smiles>[R]CC(O)OC(O)c1c[nH]c(=O)[nH]c1=O</smiles>

$177 \mathrm{R}=\mathrm{SH}$ $178 \mathrm{R}=\mathrm{NH}_{2}$
Figure 11: 5'-Modified pseudouridine 176 and secopseudouridines $177,178$.

\section{Biological activity}

A number of the previously mentioned compounds were synthesized in order to evaluate their antiviral and cytotoxic activity. Moreover, antibacterial activity of some of these derivatives has also been studied. Some of the tested compounds have shown interesting results and a brief survey is given in the following section.

\section{Antiviral activity}

Shortly after the discovery of antiviral activity of 5-ethyl-2'deoxyuridine [49], further C-5 modified analogues were synthesized and studied as potent antiviral agents. Some of the compounds prepared were 5-(1-methoxy-2-bromoethyl)-2'- deoxyuridine (12), 5-(1-methoxy-2-chloroethyl)-2'-deoxyuridine (13) $[9,50]$ and 5-(1-methoxy-2-iodoethyl)-2'-deoxyuridine (28) [10] (Figure 12). These methoxy-haloethyluridines were tested against the Herpes simplex virus type 1 (HSV-1) and their activity compared with the antiviral activity of acyclovir and BVDU (5-(2-bromovinyl)-2'-deoxyuridine). The bromo derivative 12 exhibited greater activity than the corresponding chloro analogue 13. Nevertheless, antiviral activity was weaker in comparison to acyclovir or BVDU. The most active iodo derivative $\mathbf{2 8}$ exhibited an antiviral activity approaching that of IVDU (5-(2-iodovinyl)-2'-deoxyuridine) and acyclovir.

The introduction of another halogen atom led to the preparation of 5-(1-methoxy-2,2-dihaloethyl)-2'-deoxyuridines 47-49 (Figure 13) [13]. All of these compounds were subjected to in vitro antiviral testing against $\mathrm{HSV}-1, \mathrm{HSV}-2, \mathrm{VZV}$ (Varicella zoster virus), HCMV (Human cytomegalovirus) and EBV (Epstein-Barr virus) and compared with the activity of 5-(1hydroxydihaloethyl) analogues. In general, hydroxyl derivatives were more active than methoxy derivatives 47-49 against HSV-1, HSV-2, VZV and EBV. All of the investigated derivatives 47-49 were inactive against HCMV.

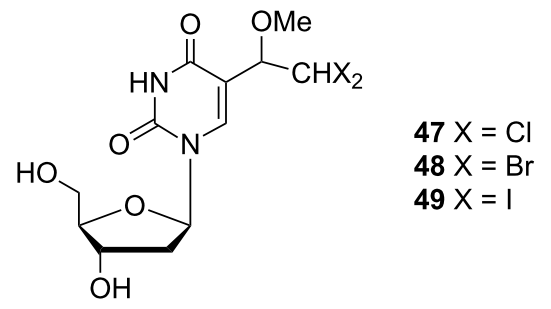

Figure 13: 5-(1-Methoxy-2,2-dihaloethyl)-2'-deoxyuridines 47-49.

Another C-5 substituted 2'-deoxyuridine analogue, 5-(1methoxyethyl)-2'-deoxyuridine (100), (Figure 14) was investigated as a potent antiviral agent against HSV-1, HSV-2 and HCMV [28]. The compound was as active as 5-ethyl-2'-<smiles>COC(CBr)c1cn(C2CC(O)C(CO)O2)c(=O)[nH]c1=O</smiles>

12<smiles>COC(CCl)c1cn(C2CC(O)C(CO)O2)c(=O)[nH]c1=O</smiles>

13<smiles>COC(CI)c1cn(C2CC(O)C(CO)O2)c(=O)[nH]c1=O</smiles>

28

Figure 12: Methoxy derivatives 12, 13 and 28. 


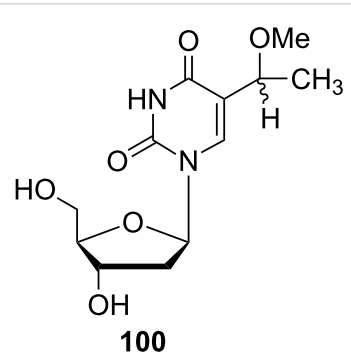

Figure 14: 5-(1-Methoxyethyl)-2'-deoxyuridine 100

deoxyuridine (EDU) against both HSV-1 and HSV-2 but less active against HCMV than EDU and ganciclovir.

The discovery of (E)-5-(2-bromovinyl)-2'-deoxy-4'-thiouridine (4'-S-BVDU) as a highly active agent against HSV-1, HSV-2 and VZV [29] inspired chemists to synthesize a group of 2 '-deoxy-4'-thionucleosides [30]. In this context, anomeric 2'-deoxy-5-(1-methoxyethyl)-4'-thiouridine (104) (Figure 15) was prepared and its antiviral activity evaluated. However, this thio derivative $\mathbf{1 0 4}$ did not show any significant activity.

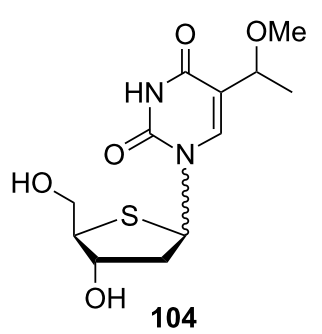

Figure 15: 2'-Deoxy-5-(1-methoxyethyl)-4'-thiouridine (104).

Amongst the mentioned derivatives, azido nucleoside $\mathbf{9 3}$ (Figure 16) was prepared in order to determine antiviral activity against HSV-1, HSV-2, VZV and HCMV [24]. However, this compound also did not exhibit significant antiviral properties.

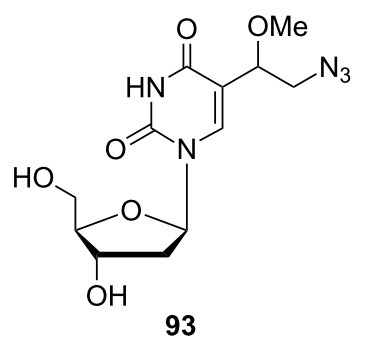

Figure 16: 5-(1-Methoxy-2-azidoethyl)-2'-deoxyuridine (93).

Recent research dealing with new antiviral agents has been focused on the study of the antiviral activity of 5-[1-(2-halo(or nitro)ethoxy-2-iodoethyl)]-2'-deoxyuridines 50-54 (Figure 17) [16]. These nucleosides were evaluated in vitro for inhibitory activity against thymidine-kinase (TK) positive and negative strains of Herpes simplex virus type-1. All of these 2'-deoxyuridine analogues exhibited only weak anti-HSV-1 activity.<smiles>[R]OC(CI)c1cn(C2CC3OCC2O3)c(=O)[nH]c1=O</smiles>

$50 \mathrm{R}=\mathrm{CH}_{2} \mathrm{CH}_{2} \mathrm{Br}$

$51 \mathrm{R}=\mathrm{CH}_{2} \mathrm{CH}_{2} \mathrm{Cl}$

$52 \mathrm{R}=\mathrm{CH}_{2} \mathrm{CH}_{2} \mathrm{NO}_{2}$

$53 \mathrm{R}=\mathrm{CH}_{2} \mathrm{CBr}_{3}$

$54 \mathrm{R}=\mathrm{CH}_{2} \mathrm{CCl}_{3}$

Figure 17: 5-[1-(2-Halo(or nitro)ethoxy-2-iodoethyl)]-2'-deoxyuridines 50-54.

\section{Cytotoxic activity}

Only a few derivatives have been tested for their anticancer properties. The cytotoxic activity for derivatives 12, 13 and 28 (Figure 12) were determined by an in vitro L1210 assay [9,10]. However, a comparison of the results for the investigated compounds with those of the reference compound melphalan showed lower activity.

Recent studies on cytotoxic activity of 5-[alkoxy-(4-nitrophenyl)methyl]uracil analogues 124, 126 and 127 (Figure 18) have been published $[34,35]$. All of the prepared compounds were tested for their cytotoxic activity in vitro against different cell lines and relationships between structure and cytotoxic activity were evaluated. Although all of the tested compounds exhibited weaker activity than reference carboplatin or 6-thioguanine, interesting relationships between activity and length of alkyl chain were observed.

\section{Antibacterial activity}

The recurrence of the chronic infectious disease tuberculosis has initiated research on new classes of antimycobacterial agents. The exigency of new drugs was also caused by multidrug-resistant tuberculosis strains, which are resistant to the most widely used agents, either Isoniazid or Rifampicin, and the need for new highly active compounds is increasing. Tuberculosis is caused by species of the genus Mycobacterium, for instance, Mycobacterium tuberculosis, Mycobacterium avium and Mycobacterium bovis.

Recently, a study on the effect of arabinofuranosyl analogues against Mycobacterium was published [19]. A series of 1- $\beta$-D2 -arabinofuranosyl pyrimidine nucleosides was prepared in order to evaluate their antimycobacterial activity. Amongst others, the methoxyiodoethyl pyrimidine nucleoside $\mathbf{7 9}$ 
<smiles>[R]OC(c1ccc([N+](=O)[O-])cc1)c1c[nH]c(=O)[nH]c1=O</smiles>

124<smiles>[R]OC(c1ccc([N+](=O)[O-])cc1)c1cn(C2OC3OC(CO)C(O2)C3[Y70])c(=O)[nH]c1=O</smiles>

i) $\mathrm{R}=\left(\mathrm{CH}_{2}\right)_{8} \mathrm{CH}_{3}$

j) $\mathrm{R}=\left(\mathrm{CH}_{2}\right)_{9} \mathrm{CH}_{3}$

k) $\mathrm{R}=\left(\mathrm{CH}_{2}\right)_{10} \mathrm{CH}_{3}$

l) $\mathrm{R}=\left(\mathrm{CH}_{2}\right)_{11} \mathrm{CH}_{3}$ m) $R=i \operatorname{Pr}$

n) $\mathrm{R}=s-\mathrm{Bu}$

o) $\mathrm{R}=t-\mathrm{Bu}$

Figure 18: 5-[Alkoxy-(4-nitrophenyl)-methyl] uracil analogues 124, 126 and 127.<smiles>COC(CI)c1cn(C2OC3C(O)C(CO)OC32)c(=O)[nH]c1=O</smiles>

Figure 19: Methoxyiodoethyl pyrimidine nucleoside 79

(Figure 19) was synthesized. Nevertheless, this nucleoside did not show any significant antimycobacterial activity.

In addition to this, nucleosides containing a dodecynyl moiety instead of an alkoxyhaloethyl group proved to be significantly active. The introduction of longer alkynyl chains might be a successful way to obtain potentially active antimycobacterial drugs.

Recently, the antimicrobial activity of 5-[alkoxy-(4nitrophenyl)methyl]uridines 126, 127 has been studied [35]. Eight isomers with different alkyl side chain lengths, 126 and 127 (Figure 20), were tested for their antimicrobial activity against standard reference gram-positive and gram-negative bacterial strains such as Enterococcus faecalis CCM 4224, Staphylococcus aureus CCM 3953, Escherichia coli CCM 3954 and Pseudomonas aeruginosa CCM 3955 and against grampositive and gram-negative bacteria obtained from clinical material of patients treated at the University Hospital in Olomouc (methicillin resistant Staphylococcus aureus - MRSA, Staphylo- coccus haemolyticus, Escherichia coli and Pseudomonas aeruginosa) with resistance to currently used fluoroquinolones. Only the octyl and nonyl derivatives $126 \mathbf{h}, \mathbf{1 2 7} \mathbf{h}$ and 126i, 127i showed slight activity against Enterococcus faecalis CCM 4224, Staphylococcus aureus CCM 3953, Staphylococcus aureus (MRSA) and Staphylococcus haemolyticus.

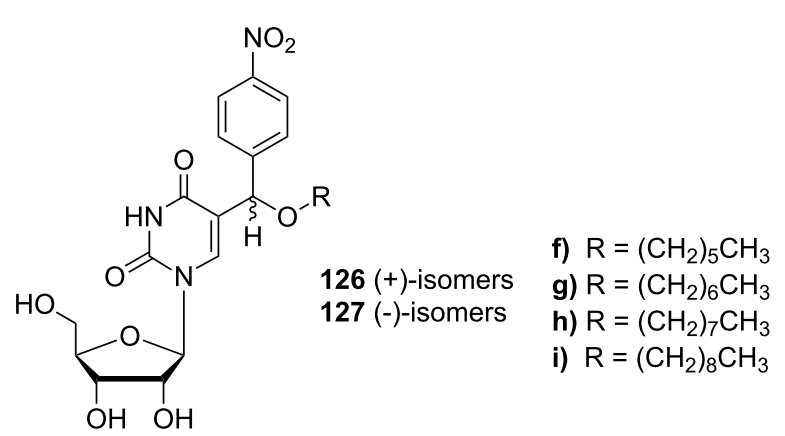

Figure 20: 5-[alkoxy-(4-nitro-phenyl)-methyl]uridines 126 and 127.

\section{Conclusion}

This review was an attempt to summarize all available information on the synthesis and biological activity of selected C-5 substituted pyrimidine derivatives. Many authors have reported facile and successful syntheses by a large range of methods to obtain the desired compounds, and, in addition, they have also highlighted ineffectual synthetic routes. Most of the published derivatives were biologically inactive; although some exhibited weak activity. However, all of these results have made a significant and invaluable contribution to the development of new potent antiviral, cytotoxic or antibacterial agents and have elucidated possible structure-activity relationships. 


\section{Acknowledgements}

The authors are grateful to the Ministry of Education, Youth and Sport of the Czech Republic, for the grant MSM6198959216 and for project CZ.1.07/2.3.00/20.0009 with funding from the European Social Fund. The infrastructural part of this project (Institute of Molecular and Translational Medicine) was supported from the Operational Program Research and Development for Innovations (Project CZ.1.05/2.1.00/ 01.0030).

\section{References}

1. Heidelberger, C.; Chaudhuri, N. K.; Danneberg, P.; Mooren, D.; Griesbach, L.; Duschinsky, R.; Schnitzer, R. J.; Pleven, E.; Scheiner, J. Nature (London, U. K. ) 1957, 179, 663-666. doi:10.1038/179663a0

2. Ive, F. A. B. J. Dermatol. 1964, 76, 463-464. doi:10.1111/j.1365-2133.1964.tb15485.x

3. McCallum, D., I; Johnston, E. N. M.; Raju, B. H. B. J. Dermatol. 1964, 76, 459-462. doi:10.1111/j.1365-2133.1964.tb15484.x

4. De Clercq, E.; Descamps, J.; De Somer, P.; Barr, P. J.; Jones, A. S.; Walker, R. T. Proc. Natl. Acad. Sci. U. S. A. 1979, 76, 2947-2951. doi:10.1073/pnas.76.6.2947

5. Cheng, Y. C.; Domin, B. A.; Sharma, R. A.; Bobek, M. Antimicrob. Agents Chemother. 1976, 10, 119-122.

6. Wataya, Y.; Matsuda, A.; Santi, D. V.; Bergstrom, D. E.; Ruth, J. L. J. Med. Chem. 1979, 22, 339-340. doi:10.1021/jm00190a001

7. Bergstrom, D. E.; Ruth, J. L. J. Am. Chem. Soc. 1976, 98, 1587-1589. doi:10.1021/ja00422a056

8. Bergstrom, D. E.; Ruth, J. L.; Reddy, P. A.; De Clercq, E. J. Med. Chem. 1984, 27, 279-284. doi:10.1021/jm00369a009

9. Kumar, R.; Wiebe, L. I.; Hall, T. W.; Knaus, E. E.; Tovell, D. R.; Tyrrell, D. L.; Allen, T. M.; Fathi-Afshar, R. J. Med. Chem. 1989, 32, 941-944. doi:10.1021/jm00125a003

10. Kumar, R.; Xu, L.; Knaus, E. E.; Wiebe, L. I.; Tovell, D. R.; Tyrrell, D. L.; Allen, T. M. J. Med. Chem. 1990, 33, 717-723. doi:10.1021/jm00164a039

11. Kumar, R.; Wiebe, L. I.; Knaus, E. E.; Tempest, M. L. J. Heterocycl. Chem. 1991, 28, 237-240. doi:10.1002/jhet.5570280206

12. Kumar, R.; Knaus, E. E.; Wiebe, L. I. J. Heterocycl. Chem. 1991, 28, 1917-1925. doi:10.1002/jhet.5570280819

13. Kumar, R.; Knaus, E. E.; Wiebe, L. F.; Allen, T. M. Antiviral Res. 1994, 24, 315-325. doi:10.1016/0166-3542(94)90078-7

14. Rahim, S. G.; Duggan, M. J. H.; Walker, R. T.; Jones, A. S.; Dyer, R. L.; Balzarini, J.; De Clercq, E. Nucleic Acids Res. 1982, 10 , 5285-5295. doi:10.1093/nar/10.17.5285

15. Iwashina, T.; Kumar, R.; Knaus, E. E.; Wiebe, L. I. J. Labelled Compd. Radiopharm. 1990, 28, 247-255. doi:10.1002/jlcr.2580280302

16. Rai, D.; Saffran, H.; Kumar, R. J. Enzyme Inhib. Med. Chem. 2003, 18, 41-45.

17. Kumar, R.; Wiebe, L. I.; Knaus, E. E.; Allen, T. M.; Fathi-Afshar, R.; Tovell, D. R.; Tyrrell, D. L. Drug Des. Delivery 1989, 4, 227-235.

18. Ismail, M.; Zoorob, H.; Strekowski, L. ARKIVOC (Gainesville, FL, U. S. ) 2002, 1-8.

19. Johar, M.; Manning, T.; Tse, C.; Desroches, N.; Agrawal, B.; Kunimoto, D. Y.; Kumar, R. J. Med. Chem. 2007, 50, 3696-3705. doi:10.1021/jm0703901

20. Kumar, R.; Wiebe, L. I.; Knaus, E. E.; Allen, T. M.; Tempest, M. L. Drug Des. Discovery 1992, 8, 179-189.
21. Kumar, R.; Wiebe, L. I.; Knaus, E. E. Nucleosides Nucleotides 1993, 12, 537-545. doi:10.1080/07328319308021221

22. Kitano, K.; Machida, H.; Miura, S.; Ohrui, H. Bioorg. Med. Chem. Lett. 1999, 9, 827-830. doi:10.1016/S0960-894X(99)00090-6

23. Waga, T.; Nishizaki, T.; Miyakawa, I.; Ohrui, H.; Meguro, H. Biosci., Biotechnol., Biochem. 1993, 57, 1433-1438. doi:10.1271/bbb.57.1433

24. Kumar, R.; Rai, D.; Sharma, S. K.; Saffran, H. A.; Blush, R.; Tyrrell, D. L. J. Med. Chem. 2001, 44, 3531-3538. doi:10.1021/jm010226s

25. Piechowska, M.; Shugar, D. Biochem. Biophys. Res. Commun. 1965, 20, 768-773. doi:10.1016/0006-291X(65)90084-7

26. Pietrzykowska, I.; Shugar, D. Acta Biochim. Pol. 1967, 14, 169-181.

27. Bergstrom, D. E.; Ogawa, M. K. J. Am. Chem. Soc. 1978, 100, 8106-8112. doi:10.1021/ja00494a014

28. Kumar, R.; Wiebe, L. I.; Knaus, E. E. J. Med. Chem. 1993, 36, 2470-2474. doi:10.1021/jm00069a004

29. Dyson, M. R.; Coe, P. L.; Walker, R. T. J. Med. Chem. 1991, 34, 2782-2786. doi:10.1021/jm00113a016

30. Rahim, S. G.; Trivedi, N.; Bogunovic-Batchelor, M. V.; Hardy, G. W.; Mills, G.; Selway, J. W. T.; Snowdon, W.; Littler, E.; Coe, P. L. J. Med. Chem. 1996, 39, 789-795. doi:10.1021/jm950029r

31. Jones, A. S.; Slater, M. J.; Walker, R. T. J. Chem. Soc., Perkin Trans. 1 1987, 1325-1329. doi:10.1039/p19870001325

32. Mel'nik, S. Y.; Bakhmedova, A. A.; Yartseva, I. V.; Preobrazhenskaya, M. N.; Zagulyaeva, O. A.; Mamaev, V. P.; Chekunova, E. V.; Bektemirov, T. A.; Andzhaparidze, O. G. Bioorg. Khim. 1982, 8, 1102-1107.

33. Jones, A. S.; McClean, M. J.; Slater, M. J.; Walker, R. T.; Balzarini, J.; De Clercq, E. J. Chem. Soc., Perkin Trans. 1 1987, 457-464. doi:10.1039/p19870000457

34. Spacilova, L.; Dzubak, P.; Hajduch, M.; Krupkova, S.; Hradil, P.; Hlavac, J. Bioorg. Med. Chem. Lett. 2007, 17, 6647-6650. doi:10.1016/j.bmcl.2007.09.022

35. Brulikova, L.; Dzubak, P.; Hajduch, M.; Lachnitova, L.; Kollareddy, M.; Kolar, M.; Bogdanová, K.; Hlavac, J. Eur. J. Med. Chem. 2010, 45, 3588-3594. doi:10.1016/j.ejmech.2010.05.003

36. Sugiyama, H.; Matsuda, S.; Kino, K.; Zhang, Q. M.; Yonei, S.; Saito, I. Tetrahedron Lett. 1996, 37, 9067-9070. doi:10.1016/S0040-4039(96)02130-2

37. Kittaka, A.; Horii, C.; Tanaka, H.; Miyasaka, T.; Nakamura, K. T.; Kuroda, R.; Sugiyama, T. Heterocycles 2004, 64, 367-382. doi:10.3987/COM-04-S(P)38

38. Kittaka, A.; Kuze, T.; Asakura, T.; Ito, K.; Miyasaka, T.; Inoue, J. I. Bioorg. Med. Chem. Lett. 1998, 8, 3207-3210. doi:10.1016/S0960-894X(98)00584-8

39. Ding, H.; Greenberg, M. M. J. Am. Chem. Soc. 2007, 129, 772-773. doi:10.1021/ja0678931

40. Sarfati, S. R.; Pochet, S.; Neumann, J. M.; Igolen, J. J. Chem. Soc., Perkin Trans. 11990, 1065-1070. doi:10.1039/P19900001065

41. Bergstrom, D. E.; Ruth, J. L.; Warwick, P. J. Org. Chem. 1981, 46, 1432-1441. doi:10.1021/jo00320a039

42. Meunier, P.; Ouattara, I.; Gautheron, B.; Tirouflet, J.; Camboli, D.; Besancon, J. Eur. J. Med. Chem. 1991, 26, 351-362. doi:10.1016/0223-5234(91)90070-4

43. Shapiro, R.; Chambers, R. W. J. Am. Chem. Soc. 1961, 83, 3920-3921. doi:10.1021/ja01479a057

44. Brown, D. M.; Burdon, M. G.; Slatcher, R. G. Chem. Commun. (London) 1965, 77-78. doi:10.1039/C19650000077 
45. Asbun, W.; Binkley, S. B. J. Org. Chem. 1966, 31, 2215-2219. doi:10.1021/jo01345a032

46. Asbun, W.; Binkley, S. B. J. Org. Chem. 1968, 33, 140-142. doi:10.1021/jo01265a026

47. Lerch, U.; Burdon, M. G.; Moffatt, J. G. J. Org. Chem. 1971, 36, 1507-1513. doi:10.1021/jo00810a016

48. Lee, M. K.; Yang, J. W.; Chun, B. K.; Kim, J. H.; Chung, W. K.; Chun, M. W. Soul Taehakkyo Yakhak Nonmunjip 1991, 16, 97-102.

49. De Clercq, E.; Bernaerts, R. J. Biol. Chem. 1987, 262, 14905-14911.

50. Mendiratta, S.; Madan, A. K. J. Chem. Inf. Comput. Sci. 1994, 34, 867-871. doi:10.1021/ci00020a021

\section{License and Terms}

This is an Open Access article under the terms of the Creative Commons Attribution License

(http://creativecommons.org/licenses/by/2.0), which permits unrestricted use, distribution, and reproduction in any medium, provided the original work is properly cited.

The license is subject to the Beilstein Journal of Organic Chemistry terms and conditions:

(http://www.beilstein-journals.org/bjoc)

The definitive version of this article is the electronic one which can be found at: doi:10.3762/bjoc.7.80 